H A R VAR D

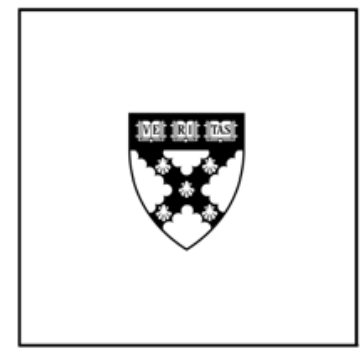

\title{
Employee Selection as a Control System
}

\author{
Dennis Campbell
}

\section{Working Paper}

11-021 


\title{
Employee Selection as a Control System*
}

\author{
Current Draft: August 2010 \\ Dennis Campbell \\ Harvard Business School \\ dcampbell@hbs.edu
}

\begin{abstract}
Theories from the economics, management control, and organizational behavior literatures predict that when it is difficult to align incentives by contracting on output, aligning preferences via employee selection may provide a useful alternative. This study investigates this idea empirically using personnel and lending data from a financial services organization that implemented a highly decentralized business model. I exploit variation in this organization in whether or not employees are selected via channels that are likely to sort on the alignment of their preferences with organizational objectives. I find that employees selected through such channels are more likely to use decision-making authority in the granting and structuring of consumer loans than those who are not. Conditional on using decision-making authority, their decisions are also less risky ex post. These findings demonstrate employee selection as an important, but understudied, element of organizational control systems.
\end{abstract}

\footnotetext{
*I thank Maria Loumioti, Tatiana Sandino, Suraj Srinivasan, Michael Toffel, Peter Tufano, and participants at the Harvard Information, Markets, and Organizations Conference for helpful comments. I acknowledge the financial support of the Division of Research of the Harvard Business School. All errors remain my own.
} 


\section{Introduction}

In this paper, I examine the relationship between employee selection and management control outcomes. Theories from the economics, accounting, and organizational behavior literatures predict that when it is difficult to align incentives by contracting on output, aligning preferences via employee selection may provide a useful alternative (Merchant 1985, Cohn and Pfeffer 1986, Simons 2000, Prendergast 2008). Moreover, there is considerable evidence that organizations devote significant resources to employee selection in settings where it is difficult to contract on output (Heskett et. al. 1997, 2003; Goodsell 2004). Despite the longstanding nature of these theories, the diversity of the disciplines in which they are posited, and their apparent importance within organizations, empirical evidence in relation to them is generally lacking.

I address this gap using personnel and lending data from a highly decentralized organization in which there is a basic management control problem - motivating employees to use decision-making authority and to do so effectively - that is difficult to solve via measuring and contracting on output. I exploit variation within this organization in whether or not employees are selected via channels that are likely to sort on the alignment of their preferences with organizational objectives.

In particular, I make use of two features of this organization that give rise to such variation. First, the organization underwent a significant change from a highly centralized structure to one that is highly decentralized. Many of the employees working in the decentralized organization were hired prior to this change while many were hired after it. I use the structure that the employee was hired into as an indirect indicator of the extent to which his or her preferences are aligned with the decentralized organization's objectives. Second, some employees are screened into the organization via its normal 
hiring processes while others are referred by existing employees. Prior literature has demonstrated that job candidates referred by the firm's current workers are more likely to survive the selection process and tend to have better post-hire career outcomes consistent with hires through this channel being better matched to their respective firms (see Fernandez et al. 2000 for a review of the literature). Consistent with this literature, I use the referral source of the employee as an additional indirect indicator of the extent to which his or her preferences are aligned with the decentralized organization's objectives.

Using these observable indicators, as well as a unique dataset linking specific employees to specific lending decisions, I establish a direct empirical link between the channel of employee selection and both aspects of the basic management control problem in this setting - the use and performance outcomes of employee decision-making authority. In particular, I find that employees selected through "more aligned" channels are more likely to use decision-making authority in the granting and structuring of consumer loans than those who are not. Conditional on using decision-making authority, their decisions are also less risky ex post. I interpret these findings in the context of prior literature as demonstrating employee selection as an important, but understudied element of organizational control systems.

This study makes two primary contributions. First, I contribute to the relatively large and multidisciplinary literature on employee selection as a management control mechanism by providing, to my knowledge, the first direct empirical evidence of a link between employee selection and better management control outcomes. In particular, my results provide evidence in support of longstanding management accounting-based models of management control which posit that control in organizations can be obtained by managing “inputs” (e.g. employee selection) rather than "outputs” (e.g. explicit incentive contracting on 
financial performance) (see Merchant 1985 or Simons 2000 for an articulation of this model). Similarly, the findings in this paper generally lend empirical support to emerging economic theories on preference alignment as a solution to contracting problems (Prendergast 2008, 2009).

Second, this paper extends the accounting-based empirical literature on organization design. Much of this literature has focused on testing theories about the interrelationships between delegation of decision-rights and incentive compensation and on selected determinants of these two choices (Nagar 2002, Abernethy et. al. 2004, Moers 2006, Campbell et. al. 2009). By focusing exclusively on the explicit incentive compensation choice, this research has tended to ignore a variety of other mechanisms that firms might use to achieve management control in delegated decision environments. The findings in this paper demonstrate that employee selection can be a solution to a fundamental accounting problem - the difficulty of defining and measuring output - that would reduce the ability for explicit contracting to solve the delegation problem.

The remainder of the paper proceeds as follows. In the next section, I briefly review the relevant prior literature. Section 3 provides a detailed discussion of the research setting and data for this study. Empirical tests and results are presented in Section 4. Finally, I conclude with a brief discussion in Section 5.

\section{Prior Literature}

The link between employee selection and better management control outcomes is a topic that has been the subject of considerable theoretical research across literatures as varied as accounting, economics, and organizational behavior. Within the accounting literature, the classic input, process, output model of management control has been a mainstay of textbooks for decades (Merchant 1985, Simons 2000). This model, among other things, posits that 
control in organizations can be obtained by managing "inputs", including employees, rather than "outputs" by, for example, explicit incentive contracting on financial performance. In this way, input based controls are fundamentally ex ante control mechanisms that are likely to be used when ex post mechanisms of management control like explicit performance contracting are difficult or unavailable. Such input based controls have also widely been referred to as "personnel controls” (Simons 2000; Merchant and Van der Stede 2007). The fundamental insight of these models of control is that more effort placed on screening employees at entry means less emphasis need be placed on monitoring them once in the organization.

In the organizational behavior literature, Ouchi (1984) posits a form of management control in organizations called "clan control” which has fundamentally similar characteristics to input or personnel controls. In particular, his notion of clan control focuses on management control via norms, shared values, and routines which are facilitated, in part, by the careful selection of employees who are likely to internalize the organization's desired values. In his theory, such clan control will arise when "rational" forms of control are unavailable due to difficulty in measuring either behavior or output.

An emerging economics literature echoes these insights but from a different perspective. Prendergast (2008) directly studies the relationship between contractability of performance measures and an organization's hiring preferences. His agency theoretic model predicts that, in the absence of perfectly contractible performance measures, organizations will in general hire "biased” agents who are disproportionately motivated to carry out only a subset of what the firm cares about with the degree of bias increasing as contracting measures get worse. The fundamental insight of his model is that when incentives cannot be aligned via explicit contracting, aligning preferences through employee selection is a viable alternative. Similar notions can be seen in the economics based literature on organizational 
culture as shared values. ${ }^{1}$ For example, a key insight of Van den Steen (2010) is that (1) all agency problems essentially arise from differences in objectives and (2) shared beliefs and values reduce or eliminate such differences in objectives. While he does not make the link to employee selection per se, his model does support a mechanism through which the selection of employees with particular beliefs or values can be a solution to agency problems.

While the theoretical literature on the link between employee selection, incentive alignment, and management control is relatively large and diverse. Empirical evidence is generally lacking with the exception of a growing empirical literature on organizational referrals as a hiring source. This literature generally shows that job candidates referred by an organization's current workers are more likely to survive the selection process and tend to have better post-hire career outcomes. One reason posited is that the referrer effectively "screens” the applicant based on superior information to that which the organization would have in the absence of referral, thus providing a more appropriate match for the organization (for review of the literature, see Fernandez et al. 2000). As described later, I rely on referral source as a proxy for the extent to which the employee's and organization's preferences are aligned.

\section{Research Setting and Data}

The research site for this study is a relatively large federal credit-union with approximately $\$ 1.3$ billion in assets, 130,000 members, 328 employees, and 23 branches operated in a single state in the U.S. ${ }^{2}$ The organization offers lending, deposit, and investment products that are similar to those offered by other retail financial services firms

\footnotetext{
${ }^{1}$ See Van den Steen 2010 for a thorough review of this literature

${ }^{2}$ Credit unions are a form of depository institution that function like banks in many respects, but which have a unique legal and organizational structure. The most salient factor that differentiates credit unions from commercial banks is the nature of their ownership. Credit unions are mutually owned and organized by their members (depositors), whereas commercial banks are owned by shareholders. Due to their mutual ownership structure, credit unions typically refer to customers as “members.”
} 
and counts national banks, community banks, and other credit unions operating within its markets as major competitors. The data for this study, described later in this section, comes from this organization's personnel and lending records during the period starting in January 2005 and ending in May 2010. Throughout this period, this organization's performance, when compared either to a peer group of same-state credit unions or to a national peer group of thirty credit unions of similar size, has consistently ranked in the top $10 \%-15 \%$ in productivity (revenue per employee), loan default rates ( $2^{\text {nd }}$ lowest), and overall performance. $^{3}$

The most salient aspect of the organization from the perspective of this paper is a significant change it underwent in its business model and associated management control systems by the end of 2004. From this period onward, traditional centralized policies and procedures for everything from waiving fees to underwriting loans were replaced by a framework that radically decentralized decision-making to employees throughout the organization - from the top executive team to customer-facing employees at the lowest level of the organizational hierarchy. ${ }^{4}$ Throughout this paper, I refer to the business model implemented in the period after 2004 as the "new system" and that implemented in the period prior to and including 2004 as the “old system”.

The new system has many features that are consistent with the theoretical literature on employee selection and organizational identity discussed above. Namely, output is difficult to measure and contract on, alignment of employee and organizational interests is

\footnotetext{
${ }^{3}$ Overall performance is measured by a commonly used metric in this industry called "Return-of-theMember" or "ROM". The ROM metric explicitly recognizes members as the organization's shareholders and its calculation considers the three core credit union functions of lending, savings and product usage with three main components: Return to the Savers, Return to the Borrowers and Member Service Usage. The ranking system is an index calculation that takes into account a credit union's performance in comparison with its asset size-based peer group.

${ }^{4}$ This includes the equivalent of tellers in its branches which the organization refers to as "member service representatives".
} 
important, and the selection of employees with particular attributes is increasingly relied on as a mechanism to solve this alignment problem.

\subsection{Difficulty Measuring and Contracting on Output}

The new system has two interrelated characteristics that give rise to challenges in measuring and contracting on output: (1) organizational objectives are stated in relatively intangible terms and (2) financial outcomes are expected to occur over relatively long time horizons. Underscoring both of these characteristics, the new system was implemented with an objective of "building relationships founded on trust" with a belief that focusing on building relationships through member advocacy and service would lead to long-term value creation for both the member and the organization.

The change towards the new system initially came about because the CEO felt that the organization was performing well from a financial standpoint but was failing to provide strong service to members. He viewed a lack of empowerment among employees as the root cause and was concerned about the implications for the organization's long-term performance. In his words, “...the best way to improve service was to move the decision as close to the member and the transaction as possible. We felt that the most effective way to accomplish that was to empower all employees to make decisions on behalf of the member.” Highlighting the willingness of the organization to trade off short-term financial performance for expected long-term gains from the model, internal business plan documents noted that “...to achieve the successful implementation of our [strategy], we are willing to forgo revenue and/or increase expenses, if necessary, even to the point of allowing our CAMEL rating to drop to a $2 .{ }^{\text {,5 }}$

\footnotetext{
${ }^{5}$ The CAMEL rating system was used by the NCUA to monitor the viability of credit unions. The ratings were based upon an evaluation of five critical elements of a credit union's operations: Capital Adequacy, Asset Quality, Management, Earnings and Asset/Liability Management. Credit unions were rated using a
} 
Attendant with the objective of "building relationships founded on trust" was a focus on putting members first in organizational decision-making. To facilitate this "member-first" philosophy, authority over virtually any decision involving a member was heavily decentralized throughout the organization. For example, a relevant excerpt from internal documents that were used to communicate the change to employees read:

\begin{abstract}
No employee will ever get in trouble for doing what is right for the member [bold emphasis in original document]. While this may seem like a simple statement, it is not a hollow commitment. Every employee, every manager, every executive has to believe this and more importantly, demonstrate our commitment to it, every day. I feel so strongly about this that I want to learn firsthand if you see an example where someone is not demonstrating this commitment. Please let me know immediately. After all, I cannot help you with something I do not know about.
\end{abstract}

There is only one operating policy or guideline you ever need. Trust your feelings - if it feels right and makes sense, do it on behalf of the member. Do not consider the system capability, policy, or procedure - err on doing whatever is necessary for the member and allow your manager or supervisor to take care of the rest. Finally, be prepared to defend your decision! If your intention is to do what is right for the member, you have the support of management and your co-workers.

While it gave employees at all levels of the organization wide latitude in their interactions with members over a range of decisions, the loosening of traditional controls, and resulting decentralization of decision-making authority, would have its most immediate effect on the organization’s lending practices. As one executive explained: “Employees were given full latitude on rates and overriding our underwriting guidelines. Even [tellers] had this authority.” By contrast, under the old system, as with most banks and credit unions, the organization automated underwriting using FICO scores and other risk scoring methodologies to determine who should and should not get a loan or even an account with

combination of financial ratios and examiner judgment. CAMEL ratings ranged from 1 to 5 with 1 indicating safe and sound operations and 5 indicating poor performance in need of immediate remediation. A CAMEL rating of 2 indicated "satisfactory performance that consistently provided for safe and sound operations”. (NCUA Letter to Credit Unions, Letter No. 161, December 1994) 
the institution. Under the old system, the application of a scoring matrix for underwriting and decision-making did not allow for exceptions by the typical employee opening a loan account or processing a lending transaction for a member.

As a mechanism for guiding employee decisions, the organization's "member-first” philosophy was explicitly codified in a framework internally referred to as "Member, Organization, Employee”, or “MOE”. Extensive efforts were undertaken to communicate this framework throughout the organization, and the following excerpt from one internal document that was used in these efforts explains the concept:

... MOE was introduced as a tool to help you determine what is right for the member. MOE - Member, Organization, Employee is your guide. Not sure what's right in a particular situation? Run it through MOE - in priority order - remembering that the member always comes first and trumps the other two. In other words, if a solution is right for the employee or the organization but does not position the member for future success, we will not proceed. [Italic emphasis in original communication]

To facilitate sound decision-making under MOE as the organization grew and hired new employees after 2004, the top executive team developed and disseminated the first of what would be a series of white papers to all employees titled "Managing the Paradox". The white paper was intended to serve as a guide for utilizing MOE in decision-making. It documented several examples of situations where the " $\mathrm{M}$ " and the "O" in MOE might be in conflict and provided suggested resolutions to these situations. For example, one entry in the white paper presented the stark example of a customer walking into a branch and asking an employee for a $10 \%$ rate on a certificate of deposit when the organization's offered rate was only $4 \%$. The white paper suggested that the employee should start with the member, but consider the organization for such a significant deviation from it's current pricing. As an example, the white-paper guided the employee to ask: "Do I need to give the $10 \%$ rate or can I give $6 \%$ and still do what is right for the member?” 
The most important aspect of this framework is that it explicitly prioritizes the customer in the employee decision-making process, yet also asks them to consider the organization's success when making these decisions. The implementation of the MOE framework, and attendant decision-making authority delegated to employees, is a rather explicit recognition by the top executive team that it is difficult to measure and manage centrally in the new system due to the intangible nature of objectives such as "building relationships", generating "trust" among members, and "putting the member first". A related challenge is measuring the interrelationships among the actions of individual business units or employees, the achievement of these organizational objectives, and their ultimate long-term financial performance consequences. Decentralized decision-making authority, along with the MOE framework, places the interpretation of these objectives and the assessment of their tradeoffs with organizational performance in the hands of individual employees on a case-by-case basis in the provision of service to members.

The organization does extensively monitor a variety of financial performance metrics and has made attempts to measure its more intangible objectives - surveying members on their level of trust in the organization for example. However, these latter types of measures are the subject of ongoing improvement efforts and are relied on primarily as subjective inputs into organizational performance reviews rather than for business unit or individual performance evaluation. In short, contracting measures are relatively difficult to develop and apply in the new system. This is in contrast to the old system in which standard performance metrics, such as the number of additional products sold, were used to evaluate individuals and business units.

\subsection{Alignment of Employee and Organizational Interests}

The new system yields an obvious incentive alignment problem: motivating employees both to use decision-making authority in service provision and to do so in a way that leads to 
better financial performance in the future. Both aspects of this incentive alignment problem can be seen early in the implementation of the new system.

Speaking to the challenge of getting employees to exercise decision-making authority, the CEO noted that “...employees would say they understood our member-first philosophy, but would come back the next day and do business as usual. We communicated to employees extensively that you are empowered, you can circumvent controls, and we really want more exceptions. Yet, hesitance to deviate from standard protocols was pervasive.” Another senior executive attributed much of the reluctance among employees to the previous control systems in place at the organization. She elaborated: “Controls were extremely tight here. Our divisions were run as fiefdoms. You couldn't even get a fee waived for a member without going through accounting.”

The second part of the incentive problem - motivating employees to use decisionmaking authority effectively - was also apparent early in the implementation of the new system. While well intentioned, much of the early decision-making by employees was not well directed. One senior executive elaborated: "There was a period early on where employees were doing crazy things like driving across the state to help members, praying with members, and underwriting \$18 loans. One employee went and inspected a used car for a member." She continued: "We had to ask ourselves: how do we direct this engagement without dampening it?”

Addressing this problem led the organization to adopt many practices that prior literature would predict to find in organizations where outcomes are difficult to measure and contract on. Most important from the perspective of this paper is an increasing reliance on employee selection. However, I first describe two other mechanisms here to provide a more complete picture of the research setting: (1) subjective performance evaluation and (2) the establishment of norms and shared values for decision-making. 
First, and consistent with literature in both accounting and economics, the use of subjective performance evaluation is relied on extensively in this organization (Baker et. al. 1994, Ittner et. al. 1994, Gibbs et. al. 2004). Each of the organization's business unit "leaders" was accountable for ranking the performance of individuals on their team. Subjective performance rankings of employees were based on factors such as how well the employee was perceived as connecting with members, how well they were making decisions on behalf of the members first rather than focusing on policy or procedure, how well they were using empowerment to ensure the best outcome for the members, and on how well they could articulate the rationales for their decisions. Based on this assessment, employees were assigned a performance rating of “A+”, “A”, “ $B$ ”, or " $C$ ”. Each business unit leader was then assigned a "pool" of bonus recognition dollars based on the number of individuals on their team and overall performance from that team during that year. Each leader would then allocate an individual dollar amount to each employee based on their performance ranking. Subjective performance evaluation of this type has been in place throughout the implementation of the new system. ${ }^{6}$

Second, and consistent with Ouchi's (1979) model of clan mechanisms of control as well as economic models of "culture” in organizations (Van den Steen 2010), there is extensive reliance in this organization on norms and shared values to guide employee behavior. Norms for decision-making have evolved at this organization via at least three mechanisms. The first, as discussed above, is the articulation of the "MOE" decisionframework and the attendant white papers disseminated to facilitate its interpretation. It is worth noting that at least by 2009, employees seem to have developed a relatively nuanced

\footnotetext{
${ }^{6}$ In unreported tests, I examined these subjective performance ratings to test for the presence of implicit incentives that might shape how employees perceive and exercise decision-making authority. I find no evidence of such implicit incentives. In particular, the likelihood of a lower performance rating shows no statistically significant relationship to any of my measures of employee use of decision-making authority.
} 
and sophisticated interpretation of how to apply the MOE decision-filter. Qualitative evidence of this can be seen in Appendix A where I have provided a random sample of twenty employee written responses to a question on an internal survey conducted by the organization across its entire employee base.

The question, designed to elicit employees' understanding of the extent of their decision-making authority as well as its proper application, was posed as follows: "An employee comes to you with a member situation that, if the decision is made to go ahead with the request, will require working "outside the box." What advice would give the employee on decision making and execution?" Consistent with the development of norms, the answers to this question reveal several common elements across employees as follows: (1) Decisionmaking authority for employees in this organization is "real”. Employees by and large view very few, if any, limits on the decisions they can make on the behalf of members. (2) Employees do not tend to interpret the MOE framework naively. Rather than doing whatever the member asks for, employees carefully deliberate whether a course of action is in the longrun financial best interest of the member and believe that doing so will also be in the long-run best interest of the organization. (3) Employees appear to hold themselves accountable for following up with decisions after they are made, both in the short and long-term, to ensure the desired outcome for both the member and the organization.

The second mechanism for norm development is straightforward. Based on my own interviews and direct observation of work at this organization, employees within the same business unit interact extensively with each other when faced with significant exceptions both to elicit the views of others who have made such exceptions in the past as well as to sharpen their own rationale for making or not making the exception. 
The third mechanism for the development of norms is due to what is referred to internally as a "detection control” model based on exception reports. ${ }^{7}$ This control model functions by allowing employees to deviate from formal guidelines, but requires them to explain and document their decisions when they do so. In the context of lending decisions, one executive captured the workings of this control system in the following description:

We flag loans that are outside of our lending guidelines. If there is a rate exception, then the employee should log the explanation in [our internal IT system]. If they don't, we will have a discussion with the employee's manager to make sure the documentation is in the system going forward. If they put the explanation for their exceptions in [the system], then we don't review the exception further.

Importantly, this process only enforces the documentation of employee rationales for deviating from organizational guidelines but does not follow up to monitor or document the outcomes of these decisions. This was a deliberate choice within the organization under the assumption that monitoring and documenting outcomes would effectively eliminate employee willingness to exercise decision-making authority. ${ }^{8}$ The system does, however, maintain an electronic record of the full history of employee explanations for any lending or other (e.g. check cashing, fee-waiving) decisions for a member that deviate from the organization's formal guidelines. In this way, the system facilitates the development of norms for decision-making by maintaining an archive of past decision-rationales that any employee facing the choice to make an exception can then access to see how similar exceptions have been handled in the past.

In short, the organization uses a variety of mechanisms to motivate the effective use of decision-making authority, all of which are consistent with practices that prior literature

\footnotetext{
${ }^{7}$ In the view of the top executive team of this organization, this contrasts with the traditional "prevention" based control model of the old system which consisted of policies and procedures designed to limit employee discretion in decision-making.

${ }^{8}$ This assumption is consistent with the literature on "psychological safety" in organizations (e.g. see for example Edmondson 1999) as well as empirical work on employee behavior under different exception report regimes (Campbell et. al. 2009).
} 
would predict to find in organizations where incentive alignment is important and outcomes are difficult to measure and contract on. Similarly, and most importantly from the perspective of this paper, this organization has increasingly relied on the selection of employees with preferences aligned with its own objectives.

\subsection{Employee Selection}

Consistent with Prendergast's (2008) model of preference alignment via hiring as a solution to agency problems, the employee selection process at this organization mirrors its basic incentive alignment problem of motivating employees to use decision-making authority in member interactions and to do so effectively. In particular, the organization has actively sought to recruit employees with particular attributes that are indicative of underlying preferences for these objectives.

In my own interviews with executives and employees, a primary attribute that surfaced as important could best be described as “empathy”. Variously described in terms such as "a desire to help others", "cares for others", and "wants to make an impact on others”, this attribute is clearly seen as an indicator for a potential employee's desire to use decision-making authority on the behalf of members. Perhaps not surprisingly given the high degree of decentralized decision-making authority in the new system, other attributes that are also viewed as important are confidence in decision-making, willingness to take ownership and accept accountability, willingness to take and accept risk, and a desire to learn. ${ }^{9}$ Appendix B provides qualitative evidence on employee perceptions of the importance of

\footnotetext{
${ }^{9}$ Interestingly, employees at this organization tend to view their jobs as having very high accountability despite the lack of formal controls. When pushed on this, most seem to interpret accountability in terms of “taking ownership” for executing decisions on members' behalf and following up to ensure the desired outcomes. That is, whether due to norms or the type of employee selected, employees seem to feel a strong sense of obligation to the organization's members.
} 
these and other attributes. ${ }^{10}$ The organization's interview process naturally attempts to screen on these attributes. Typical interview questions, for example, include "If our computer system was down and a member walked in and asked you for \$500 in cash for the trip they were leaving on the very next day, how would you make that decision?”; "How do you want to be remembered by coworkers and by customers?"; and "How have you changed as an employee in the past couple of positions that you've held?”.

\subsection{Measuring Alignment of Employee Preferences with Organizational Objectives}

A feature of this organization that I exploit in my empirical tests is that employees are selected into the organization via different channels - some of which are more likely than others to identify employees with "the right" attributes. That is, some channels of employee selection within this organization are more likely than others to sort on the alignment of employee preferences with organizational objectives.

Many employees in the new system are continuing employees that were initially hired into the old system. The old system that these employees were selected into is an almost polar opposite environment to that of the new system from a management control perspective. These employees were screened into the organization initially based on very different attributes than are considered important in the new system such as prior experience in financial services organizations. Under the new system, the executive team had come to believe that past experience in another financial institution could be detrimental for a candidate attempting to transition to their model. Consistent with this, the organization recruited new employees from areas as diverse as health-care, retail, education, and realestate. The implicit assumption is that employees selected from traditional financial services

\footnotetext{
${ }^{10}$ In this appendix, I have provided a random sample of twenty employee written responses to a question on an internal survey conducted by the organization across its entire employee base. The question posed is: What personal attributes would you say are important for an employee to be successful at [the organization] in the months and years ahead?
} 
organizations will be too influenced by their own previous experience and the control structures in which they operated.

For all intents and purposes, employees who stay in the new system after being selected into the old system (“old system employees”) were initially selected into a traditional financial services organization with policy and procedure oriented management controls. Relative to employees that are hired into the new system, I expect that old system employees will have preferences that are less aligned with the organization's objectives. This is, of course, tempered by the fact that these old system employees are those who selected to remain in the new system. However, the fact that an employee was hired into the old system should be a reasonable indirect and observable indicator that his or her preferences are relatively less aligned than those of employees directly hired into the new system ("new system employees”). ${ }^{11}$

In general, I expect new system employees to have more aligned preferences than old system employees, but there are also several relevant distinctions among new system employees. Some are referred into the organization by existing employees and some come through the organization's normal screening process without referral. Further, of those that are referred, some are referred by old system employees and some are referred by new system employees. If new system employees generally have preferences that are more aligned with the organization's objectives than those of old system employees, then I expect this to extend to referrals as well. Among new system employees, those referred by other new system employees should be most aligned, those referred by old system employees should be least aligned, and employees who are screened without referral are likely to fall in between. Old system employees may also have been referred by other employees when hired

\footnotetext{
${ }^{11}$ This is consistent with Van den Steen's (2010) economic model of culture as shared beliefs in the context of mergers. Predictions from his model suggest the use of a person's pre-merger firm as an indirect, but observable, indicator of his or her beliefs.
} 
into the old system. To the extent that this led to the strongest sorting of employees who "fit" with the old system, I expect such employees to have the least aligned preferences with the new system.

Figure 1 illustrates some salient facts about the evolution of the employee selection model at this organization throughout the new system period from 2005-2010. The top lines in the figure show the percentage mix of old system versus new system employees in each year. There are two notable patterns in this data. First, as of 2005, the first full year of implementation of the new system, employees who were hired directly into this system already account for fully $40 \%$ of all employees. This pattern is consistent with a perceived need for a different "type" of employee in the new system. It also indicates significant underlying turnover of old system employees as the organization transitioned to the new system. Consistent with different employee preferences under the old system, interviews with executives and other employees suggest that this turnover was at least partially due to the discomfort of many old system employees with the level decision-making authority inherent in the new system. ${ }^{12}$

The second notable fact is that this pattern has become starker further into the implementation of the new system. Between January 2005 and May 2010, the percentage mix of old versus new system employees has shifted from 60/40 to approximately 30/70. While some of this would be expected due to normal turnover and hiring, the number of employees grew from only 300 to 328 over this period suggesting that this pattern is due to old system employees selecting, or being selected, out of the new system at a relatively high rate.

\footnotetext{
${ }^{12}$ By the end of 2004, 11 of 13 employees left the real estate services group, including both the vice president and director of lending; 8 out of 10 employees left the call center; 8 out of 23 branch managers where either let go or quit; and nearly half of the 12 member IT team quit.
} 
The bottom-line in Figure 1 shows the percentage of employees each year who were referred by existing employees. The percentage of referred employees rises from just over $30 \%$ to just over $40 \%$ during this period. As relevant, but not shown in figure 1 , is that by the end of 2009 over $50 \%$ of new employees were referred by existing employees. These patterns demonstrate increasing reliance on this recruitment channel throughout the implementation of the new system and are consistent with the literature on employee referrals as a high quality source of information for matching potential employees to particular internal labor markets (Fernandez et. al. 2000).

In summary, employee selection has played an increasing role at this organization as a mechanism for aligning employee preferences with organizational objectives. I expect such alignment to vary systematically with the channel of employee selection with the ordering from strongest to weakest alignment as follows:

1. New system employees referred by new system employees

2. New system employees who are not referred

3. New system employees referred by old system employees

4. Old system employees who are not referred

5. Old system employees referred by old system employees

If alignment of preferences via employee selection is an effective solution to the basic incentive alignment problem - in this case motivating the effective use of decision-making authority - then I expect to see more use of decision-making authority, and stronger resulting performance outcomes, in moving from the $5^{\text {th }}$ category of employee to the $1^{\text {st }}$.

\subsection{Data}

The data used for this study are collected from the organization's personnel and lending files during the period January 2005-May 2010. While decision-making authority under the new system extends to a wide range of decisions that employees might make on behalf of members, I focus on lending decisions in my analysis. Lending decisions have significant research advantages over other types of decisions for two reasons. First, 
employee use of decision-making authority is directly observable in the context of lending and might include, for example, giving a member a loan when they do not meet formal credit score guidelines. Second, and similarly, performance outcomes of these decisions are eventually observable in the form of loan default and charge-off rates. ${ }^{13}$ Lending decisions are also significant in this industry and represent one of the areas in which this organization was most impacted by the change to the new system.

The sample used for subsequent analyses consists of observations on loan, borrower, and employee characteristics for 134,121 unique loans, made to 64,540 unique borrowers, by 463 unique employees during this period. Summary statistics are provided in Table 1.

Employee Characteristics: Data on employee characteristics include the employee's year of hire into the organization, their job-title, and the business unit in which they work. ${ }^{14}$ Both job-title and business unit may vary by year. For employees who were referred into the organization, I observe the identity and year of hire of the employee's referrer. I use employee and referrer hire years to classify employees into the 5 categories noted above, defining new system employees and referrers as those hired after 2004 and old system employees and referrers as those hired prior to and including 2004.

There are 214 unique job titles in the data, but many of these are redundant, and for analysis purposes I broadly categorize employees as "customer contact” or "corporate and back office” based on these job titles and their description. Customer contact employees are

\footnotetext{
${ }^{13}$ This has a theoretical drawback in that employee selection would be predicted to have its strongest preference alignment effects in the context where output is not contractible (e.g. the provision of an "extraordinary service experience"). Technically, incentive contracts could be written on future default rates for loans made by employees. However, this could pose significant challenges by imposing risk on lower level employees making them less willing to use decision-making authority when the organization is trying to motivate them to be more willing to do so. In any case, the most relevant fact is that this organization does not contract with employees on future default rates and must rely on other mechanisms to ensure that employees make sound lending decisions. Much of my analyses examine whether this is accomplished via employee selection.

${ }^{14}$ For purposes of this study, a business unit can be a branch, a function such as financial accounting or real estate, or corporate headquarters.
} 
those whose jobs put them in contact with customers in the regular course of work and include, for example, employees working in the organization's branches and call centers. Corporate and back office employees largely consist of those working in executive or functional areas at corporate headquarters or business units other than branches or call centers.

While relatively broad, this is a good categorization for a variety of reasons. First, consistent with the decentralization of decision-making authority, every employee was expected to be capable of handling all transactions so that differences in job-tasks do not necessarily track well with differences in job-titles in the new system. This is especially true of direct customer-facing employees operating in the organization's branches and call centers as they handle the majority of transaction activity. Second, and in recognition of this fact, by 2008 the organization had itself classified all customer-contact employees into one job-title called "Member Service Representative”. Finally, as is common in most firms, customercontact employees operate at the lowest level of the organizational hierarchy. The significant decentralization of decision-making authority even to lower levels in the organization is perhaps the most unique aspect of the new system, and it is reasonable to expect that employee selection would have its strongest potential effects on management control and incentive alignment at this level.

Borrower Characteristics: Data on borrower characteristics include the borrower's credit score and debt-to-income ratio at the time their loan application is processed.

Loan Characteristics: For each loan made during 2005-2010, I observe the loan type, dollar amount, interest rate, and term at the time the loan was funded. There are three broad categories of loans in the data: secured vehicle loans used primarily for automobile purchases; personal lines of credit including credit cards and signature loans; and mortgages and home equity loans. The distribution of loans and their characteristics by type are 
provided in Table 2. In addition to these basic loan characteristics, I also observe of a variety of different types of loan exceptions which are direct indicators for whether an employee exercised decision-making authority in a particular lending decision. There are two basic types of lending exceptions: (1) those made in approving a loan and (2) those made in structuring a loan.

Loan approval exceptions occur when an employee overrides the organization's system-based guidelines in approving a potential borrower for a loan. In general, in the absence of decentralized decision-making authority at this organization, borrowers with either credit scores less than 620 or debt-to-income ratios above $45 \%$ would not qualify for approval. The benchmark of denying a loan to a borrower which falls short of either of these criteria serves as the counterfactual for what the lending decision would be in the absence of decision-making authority. This serves as a useful benchmark for examining variation in the use and outcomes of decision-making authority across employees. Throughout this paper, I use the term "system-deny" to denote loans which would have been denied in the absence of decision-making authority.

I observe loan approval exceptions in the data in two different ways. First, for every loan that was approved over the sample period, I can observe whether it is a "system-deny" loan. That is, whether it is a loan for which a credit-score exception, debt ratio exception, or both were made. This allows me to examine whether these types of loans are systematically more or less concentrated among different types of employees. In essence, this data allows me to examine the probability that a system-deny loan would be observed conditional on having been approved by a particular employee. A clear drawback of this measure is that it is a joint-probability of a system-deny borrower requesting a loan from the employee and the employee making the exception to approve the loan conditional on that request. The focus of this study is on the latter, and in some of my tests I will attempt to deal with this issue by 
controlling for factors that would make it more likely for an employee to interact with riskier borrowers.

I also address this issue via the second way in which I observe loan approval exceptions. For the period 2006-2009, I was able to obtain data on all applications from potential borrowers who were denied for loans. The data on which specific employees made the denial decision are only available for 2007, so most of my analyses of this particular data are restricted to this year. While only for a limited portion of my sample period, this type of data is not typically available in studies on lending decisions, and it allows me to directly estimate the probability of an employee approving a loan conditional on the potential borrower not meeting system criteria for approval.

The second type of loan exception - those made in the structuring of approved loans - are relatively more straightforward and consist primarily of rate exceptions. Rate exceptions occur when employees structure the loan with a different rate than what is recommended on the organization's "rate sheet” for a loan with similar characteristics. In the vast majority of cases, though not all, the actual interest rate is lower than the rate-sheet rate consistent with employees using decision-making authority largely to reduce rates offered to members. Another type of exception that can be made in the structuring of a loan is a term exception. Term exceptions occur when the employee extends the term of the loan beyond the maximum term suggested by organizational guidelines for loans with similar characteristics. However, I focus my analysis on rate exceptions as term exceptions happen rarely in the data and provide little opportunity for systematic analysis. Follow up conversations with executives and employees regarding these exceptions suggest that their relative rarity is primarily due to employee interpretation of the "MOE" decision framework - employees generally do not view extending the term of a loan to be in the long-run financial best interests of the member. 
Finally, as additional controls in my analysis of lending decisions, for each loan made by an employee I construct two measures of lending experience in the new system. First, I measure the employee's general prior experience with lending decisions in the new system as the cumulative number of loans made by the employee up to and excluding the current loan. Second, I measure the employee's experience lending to a specific member as the number of prior loans made by the employee to that member. The cumulative number of loans in both cases is measured from January 2005 or from the employee's hire date, whichever is later. I include these measures as controls for any potential learning effects in the data over time and because employees who repeatedly interact with specific members could reasonably be expected to have better "local information" on the member's credit-worthiness independent of the characteristics of the employee.

Loan Performance Outcomes: I am able to observe whether an outstanding loan is charged off between January 2008 and May 2010 irrespective of when the loan was originated. A charge-off is a loan that is written off as uncollectible bad debt and is clearly the most extreme outcome of a poor performing loan. It would be ideal to have intermediate outcomes such as defaults on loan payments, but I do not observe such outcomes in this data. While the performance outcome is relatively extreme, this data allows for direct tests of the performance implications of employee decision-making authority in lending decisions.

\section{Empirical Tests and Results}

\subsection{Descriptive Statistics on the Use of Decision-Making Authority}

Before turning to formal tests of the relationships between the channel of employee selection and the use and outcomes of decision-making authority, I first examine several suggestive patterns in the data that illustrate the nature of employee lending decisions in this research setting. Data presented in Table 1 as well as Figures 2-4 provide strong evidence that decision-making authority in this setting is "real" rather than simply formal or 
perceived. $^{15}$ Table 1 shows that $13 \%$ of all loans approved during 2005-2010 were approved with credit-score exceptions, $24 \%$ were structured with interest rate exceptions, and fully 73\% of all loan applications from “system-deny” borrowers were approved in 2007.

Figure 2 demonstrates that decision-making authority is also highly dispersed across this organization. With the exception of 2008, a year in which overall loan applications declined, every employee made at least one lending decision and this remained at approximately $90 \%$ of all employees even in $2008 .{ }^{16}$ Moreover, the top $20 \%$ of employees in terms of loan volume in a given year account for less than $60 \%$ of all lending decisions with slightly less concentration when the sample is limited to customer-contact employees. Lending activity would have been highly concentrated in few employees in the old system and the ability to make exceptions even more so. Figure 3 shows the distribution of the number of loans per employee per year and demonstrates that, in a typical year, approximately $60 \%$ of all employees approve more than 25 loans with the number ranging widely to well over 500 .

The net effect of this widespread use of decision-making authority, as shown in Figure 4, is that the organization is approving many loans that would otherwise be denied by system-rules based on credit scores and debt ratios. The approval rate on such loans varies between $60 \%$ and $80 \%$ from 2006-2009. Employees appear to view credit score exceptions as riskier decisions than debt-ratio exceptions as evidenced by the relatively lower $50 \%-70 \%$ loan approval rate for borrowers that do not meet credit score criteria

\footnotetext{
${ }^{15}$ I use these terms in the sense of Aghion and Tirole‘s (1997) notion of formal versus real authority. Employees in my research setting have clear formal decision rights to deviate from lending guidelines, but their real authority would be limited if they perceived the threat of implicit punishments from superiors monitoring their use of such formal authority.

${ }^{16}$ Note that this includes all employees - even those in corporate and "back office" positions. These employees get opportunities to make loans because the organization has an IT system that routes any "overflow" calls in its call centers randomly throughout the organization. When call centers are busy, any employee in the organization can receive a randomly routed call from a member regarding lending or other transactions and is expected to handle the transaction.
} 
4.2 Does the use of Decision-Making Authority Vary with the Channel of Employee Selection?

Table 3 provides evidence of systematic and predictable variation in the use of decision-making authority across employee categories. Several patterns in Table 3 are worth noting - particularly for customer contact employees. First, all types of employees appear to utilize decision-making authority relatively extensively. Even old system employees referred by old system employees - the category that is expected to be the most reluctant to use decision-making authority - approve $71 \%$ of loans from system-denied applicants and make rate exceptions on 23\% of approved loans. Not surprisingly since these employees selfselected to remain in the organization, they appear to have "adapted" to the new system. Despite this, the second pattern of note in Table 3 is that employees hired into the new system are significantly more likely to use all types of decision-making authority than old system employees. This is true across all categories of new system employees. These predictable patterns also remain when comparisons are restricted to within new system employees - with those referred by other new system employees showing significantly higher loan exception rates across all exception types.

Some of these general patterns remain for corporate and back office employees, particularly the comparisons between old and new system employees, but the results are not as strong in this sample of employees. In particular, there is little distinction in the use of decision making authority across loan exception types for new system employees who are not referred when compared to those who are referred by other new system employees. As noted earlier, it is reasonable to expect employee selection to have stronger effects in this setting among customer-contact employees, but these weaker patterns may also be due to smaller sample sizes of employees or loans within the corporate and back-office employee group. 
The patterns documented in Table 3 largely remain when lending decisions are subjected to a multivariate analysis controlling for factors other than employee characteristics that are expected to influence these decisions. Table 4, Panel A, reports results from estimating logit models for the different categories of lending exceptions for the sample of customer-contact employees. The excluded employee category in each model is old system employees referred by old system employees. To control for unobserved heterogeneity across lending decisions, all models include fixed effects for loan-type, business unit, and year. Reported standard errors are corrected for clustering of observations within employees prior to inference.

The first column contains coefficient estimates for the model predicting the probability of an approved loan being one for which a credit score exception was made. The results demonstrate that loans with credit-score exceptions are more likely to be observed if the employee making the lending decision has had prior lending experience with the borrower on the loan, and they are less likely for larger loans. More importantly, the coefficient estimates show that the predicted patterns in the use of decision-making authority across employee categories remain: new system employees show higher conditional rates of credit-score exceptions than old system employees generally, with the highest rates demonstrated for new system employees referred by other new system employees.

These results may be confounded if different employee groups are systematically more likely to interact with riskier borrowers. This may arise, for example, if different types of employees are concentrated in particular business units due to the hiring preferences of the manager, the local labor market, prior employee turnover or other factors and if there are systematic differences in the types of borrowers that interact with particular business units. By including business unit fixed effects in our analyses, we partially control for these potential confounding factors. However, the types of borrowers interacting with business 
units may change over time, and this will not be picked up with branch fixed effects. To remedy this, the second column in panel A of Table 4 adds a measure of the average credit score of borrowers whose loans were originated at the business unit in the prior year. Not surprisingly, increases in the average credit quality of borrowers interacting with a business unit are negatively associated with the likelihood of observing a loan with a credit score exception. More importantly, the results on differences in conditional exception rates across employee categories are robust to the inclusion of this measure. The coefficient estimates on the employee category indicators suggest that, relative to old system employees referred by old system employees, the implied marginal effects for new system/referred by old system, new system/not referred, and new system/referred by new system employees are approximately $1 \%, 1 \%$, and $3.3 \%$ respectively. Relative to the $11 \%$ mean rate of credit score exceptions for old system/referred by old system employees, these imply increases of $9.1 \%$, $9.1 \%$, and $30 \%$ respectively.

The results in the first two columns of Table 4, Panel A, demonstrate that credit score exceptions are more likely to be observed among new system employees, particularly those referred by other new system employees. The next two columns show the flip-side of this, the probability that these employees will accept a loan from a borrower who does not meet credit score or other system criteria. In these tests, I control directly for characteristics of the borrower by including the borrowers debt-to-income ratio and "credit grade". ${ }^{17}$ The credit grade is used internally as a way to classify borrowers by credit score and ranges from “A+" to "D”. Cutoff values of credit score are used to grade each borrower with credit grades " $C$ " and "D" consisting of borrowers with credit scores lower than the system criteria of 620 . I use the credit grade rather than the credit score in recognition of the inherent nonlinearity in

\footnotetext{
${ }^{17}$ The logit model in column 3 of Table 4 is conditional on the loan applicant being a system-deny applicant. Variation in credit scores and debt-ratios arise in this sample of applicants because the system rule would deny applicants with either credit scores $<620$ or debt to income ratios $>45 \%$.
} 
credit-score based lending decisions. The excluded credit grade in these specifications is "B”. Not surprisingly, the results show that employees are more likely to approve loans of lower dollar amounts and from borrowers with higher credit scores, lower debt ratios, and for whom they have approved loans in the past.

More notably, the coefficient estimates show that the predicted patterns in the use of decision-making authority across employee categories remain consistent. The coefficient estimates on the employee category indicators from column 3 suggest that, relative to old system employees referred by old system employees, the implied marginal effects for new system/referred by old system, new system/not referred, and new system/referred by new system employees are approximately $2.9 \%, 3.5 \%$, and $7.8 \%$ respectively. Relative to the 71\% mean acceptance rate of system-deny borrowers by old system/referred by old system employees, these imply increases of $4 \%, 5 \%$, and $11 \%$ respectively.

Results in column 4 are similar, but the implied marginal effects are larger. This column shows a specification for acceptance rates conditional on applicants having credit scores less than 620 irrespective of their debt-to-income ratios. Relative to old system employees referred by old system employees, the implied marginal effects in this specification for new system/referred by old system, new system/not referred, and new system/referred by new system employees are approximately 8\%, 8.6\%, and 18.6\% respectively. Relative to the $64 \%$ mean acceptance rate of below credit score threshold borrowers by old system/referred by old system employees, these imply increases of $8.5 \%$, $13.4 \%$, and $29 \%$ respectively. These results suggest that using decision-making authority to override credit-score criteria is viewed as a more significant decision by employees generally, and that the "alignment effect" of the channel of employee selection is larger for this more significant decision. 
Turning to employee decisions regarding the structuring of loans, the last column in Panel A of Table 4 demonstrates that employees are more likely to make interest rate exceptions for loans with higher dollar amounts and to borrowers with lower credit scores, higher debt ratios, and for whom they have approved loans in the past. Borrowers with lower credit scores and/or higher debt ratios would not normally qualify for the organization's lowest interest rates, so it is not surprising that these are the borrowers for whom employees would offer rate reductions. Results on the use of this type of decision-making authority across employee categories are not as strong as those for loan approval decisions. New system employees referred by new system employees show the highest conditional rates of interest rate exceptions, new system employees referred by old system employees show the next highest conditional exception rates, but non-referred new system employees show no significant differences from either category of old system employee. Relative to old system employees referred by old system employees, the implied marginal effects for new system/referred by old system and new system/referred by new system employees are $1.4 \%$ and $1.8 \%$ respectively. Relative to the $23 \%$ mean rate of interest rate exceptions by old system/referred by old system employees, these imply increases of $6.1 \%$ and $7.8 \%$ respectively.

Panel B of Table 4 replicates the analysis in Panel A on the sample of corporate and back-office employees. In general, with the exception of credit score exceptions on approved loans, the results on this sample of employees are not as strong as those for customer contact employees. One possibility for the discrepancy is that coordination and alignment problems are more significant among the more numerous and geographically disperse customer-contact employees, but these weaker patterns may also be due to smaller sample sizes of employees or loans within the corporate and back-office employee group. 
Overall, the results in this section - at least those regarding customer contact employees where the incentive alignment problem is most severe - provide evidence that the use of decision-making authority is significantly higher for employees selected via channels that are likely to sort on the alignment of their preferences with organizational objectives. These findings do not, however, establish whether there is differential effectiveness in the use of this authority across employees selected via different channels. This is the issue I turn to next.

\subsection{Do Decision-Making Outcomes Vary with the Channel of Employee Selection?}

I examine the effectiveness of decision-making outcomes by investigating 18-month charge-off rates for "system-deny” loans approved by employees between January 2007 and November 2008. Because I only observe charge-offs between January 2008 and April 2010, I am limited to this relatively short time period. Summary statistics on charge-off rates, both on average and across employee categories, are provided in Table 5. Not surprisingly given that system criteria are based on credit scores and debt to income ratios, both of which index the ex ante risk of borrowers, "system deny" loans show higher mean charge-off rates than loans that meet system criteria. 18-month charge-off rates are $0.4 \%$ for loans that meet system criteria and rise to $1.9 \%$ for loans that do not, with this difference significant at the $1 \%$ level.

A potentially better comparison would be to look at charge-off rates on system-deny loans versus those that are just above the system criteria for acceptance. These latter loans would be accepted in the absence of decision-making authority and would have ex ante risk that is closer to system-deny loans. To facilitate this comparison, I examined the subsample of loans which meet system criteria for debt-to-income ratios $(<45 \%)$ but that were made to borrowers with credit scores between 620 and 640. These borrowers meet system criteria but are just over the threshold credit score cutoff. The mean 18-month charge-off rate for this 
sample of loans at $1.88 \%$ is almost identical to the $1.9 \%$ charge-off rate for employee approved system-deny loans. While employees use decision-making authority to approve a significant percentage of system-deny loans per Figure 4 and Table 1, these results suggest the possibility that they are doing so in a way that does not appreciably increase short-term risk relative to system-based lending criteria.

Turning to differences across employee categories, Table 5 demonstrates a declining pattern in charge-off rates as we move from old system/referred by old system to new system/referred by new system employees. The latter type of employee demonstrates significantly lower charge-off rates than all other employee categories. The mean charge-off rate for new system/referred by new system employees is only $0.77 \%$, nearly half that of new system/non-referred employees which show the next lowest mean charge-off rates of $1.48 \%$. All other categories of employees demonstrate mean charge-off rates in excess of $2 \%$ which are statistically indistinguishable from each other.

The results in Table 6 demonstrate that these patterns generally hold up under multivariate analysis. This table contains logit models of 18-month charge-off rates conditional on loan, borrower, and employee characteristics for the sample of customer contact employees and for the full sample of all employees. ${ }^{18}$ Conditional charge-off rates show the same pattern across employee categories as in the univariate analysis of Table 5. The coefficient estimates demonstrate the lowest conditional charge-off rates for new system/referred by new system employees when compared to all other categories followed next by new system/non-referred employees. The coefficients for the remaining employee categories are statistically indistinguishable from each other. Results are similar when

\footnotetext{
${ }^{18}$ The relatively rare nature of short-term charge-offs coupled with the lower sample sizes of loans and employees yields low power to examine these effects in the "Corporate and Back-Office" employee sample. Instead, I have chosen to include logit estimates based on the full sample of employees in Table 6 to facilitate comparison of the results with and without these employees in the sample.
} 
examining the subsample of loans which do meet credit score criteria. Results are also similar, although not as strong, when the analysis is conducted on the full sample of employees.

Overall, the results in this section provide evidence that is consistent with better control and alignment via employee selection. In particular, employees selected via channels that are likely to sort on the alignment of their preferences with organizational objectives show more effective use of decision-making authority.

\section{Discussion and Conclusions}

The link between employee selection and better management control outcomes is a topic that has been the subject of considerable theoretical research across literatures as varied as accounting, economics, and organizational behavior. Yet, it is one for which little if any direct empirical evidence exists. By studying a setting in which there is a basic incentive alignment problem - motivating employees to use decision-making authority and to do so effectively - that is difficult to solve via measuring and contracting on output, I am able to provide direct evidence of this link.

The findings in this paper generally lend empirical support to emerging economic theories on preference alignment as a solution to contracting problems (Prendergast 2008, 2009), but patterns in the statistical and qualitative data from this organization suggest potentially useful modifications to these theories. In particular, these theories predict a type of conflict in organizations which rely on such mechanisms - as output becomes less contractible, organizations will increasingly hire employees who care about only one aspect of their job (e.g. service provision) while ignoring others (e.g. cost control). Thus, these theories paint a picture of extreme divergence of interests between management and employees in settings where output is non-contractible. 
Yet, the quantitative and qualitative evidence presented in this paper demonstrate a setting in which employees appear to balance organizational interests in their decisions despite being highly motivated and directed to focus on service provision to customers and in the absence of strong explicit or implicit incentives linked to organizational performance. Employee comments in Appendix A as well as my own interviews and observation suggest that this arises, at least partially, because employees rather explicitly recognize the link between the organization's performance and their ability to continue to provide service in the future.

Thus, while employees may be intrinsically motivated to focus on one task (service provision) at the expense of others (cost control), their beliefs about the impact of ignoring the task for which they are not motivated on their ability to carry out the task for which they are motivated may lead them to at least partially internalize an organization's performance objectives. Building such beliefs into models of preference alignment as a solution to agency problems may yield novel predictions about the costs and benefits of relying on employee selection as a control system.

The empirical results and qualitative data presented in this paper also suggest a potentially fruitful avenue of future research in the accounting literature. One the one hand, the empirical results show employee selection as a solution to a fundamental accounting problem - the difficulty of defining and measuring output in a particular context. On the other hand, there are ongoing attempts at this field site to measure performance against many of its more intangible objectives. If the performance measure "design problem” can be solved, would we see organizations move away from preference alignment and back towards traditional performance-based incentive alignment? What are the potential consequences if any? Moreover, while not discussed in detail throughout the paper, this organization has increasingly turned towards formal measurement and monitoring of its employee selection 
model - tracking, for example, employee referral rates and a variety of measures of the motivation of its workforce. Future research may be able to yield insights into the nature of performance measurement in settings where employee selection is important and output is difficult to contract on.

On a final note, a limitation of this study is that while I demonstrate better control outcomes linked to employee selection, I do not investigate the mechanism through which this occurs. In delegated decision environments like the one studied in this paper, employees selected through more aligned channels may simply have better judgment or invest more effort in acquiring local knowledge. Alternatively, such employees may invest more in learning about the organization and the resources available to them in carrying out their work. In this way, some employees may be better than others at allocating an organization's resources to achieve desired outcomes. The employee comments in Appendix A, many of which focus on the importance of "following up" on decisions, suggest that this is a potentially reasonable interpretation for the results in my research setting. Future research can make progress by investigating the potential mechanisms through which employee selection leads to better management control outcomes. 


\section{References}

1. Abernethy, M.A., J. Bowens, and L. van Lent. 2004. Determinants of control system design in divisionalized firms. The Accounting Review 79 (3): 545-570.

2. Aghion, P. and J. Tirole. 1997. "Formal and Real Authority in Organizations," Journal of Political Economy, University of Chicago Press, vol. 105(1), pages 1-29,

3. Akerlof, G. and R. Kranton. 2000. “Economics and Identity,” Quarterly Journal of Economics. Issue 3: 715-753.

4. Baker, George P., Robert Gibbons, and Kevin J. Murphy. "Subjective Performance Measures in Optimal Incentive Contracts." Quarterly Journal of Economics 109 (November 1994).

5. Campbell, D. 2008. "Nonfinancial Performance Measures and Promotion-Based Incentives,” Journal of Accounting Research. 46 (2). 1-36.

6. Campbell, D., Datar, S., and Sandino, T. 2009. "Organizational Design and Control across Multiple Markets: The Case of Franchising in the Convenience Store Industry," The Accounting Review. 84(6): 1749-1779

7. Campbell, D., M. Epstein, and F.A. Martinez-Jerez. 2009. "Implicit Control Mechanisms and Organizational Learning,” Harvard Business School Working Paper.

8. Cohen, Y. and J. Pfeffer. 1986. "Organizational Hiring Standards,” Administrative Science Quarterly. 31: 1-24

9. Edmondson, A. 1999. "Psychological Safety and Learning Behavior in Work Teams." Administrative Science Quarterly 44(4): 350-383.

10. Fernandez, R. M., E. Castilla, P. Moore. 2000. "Social capital at work: Networks and employment at a phone center," American Journal of Sociology. 105(5) 1288-1356.

11. Gibbs M., Merchant K., Van der Stede W., Vargus M., 2004. Determinants and Effects of Subjectivity in Incentives, The Accounting Review, vol.79, No.2, pp.409436.

12. Goodsell, C. 2004. The Case For Bureaucracy. Washington, DC: CQ Press.

13. Heskett, James L., W. Earl Sasser Jr., and Leonard A. Schlesinger. The Value Profit Chain: Treat Employees Like Customers and Customers Like Employees. N.Y.: The Free Press, 2003.

14. Heskett, J., W. E. Sasser Jr., and L. Schlesinger. The Service Profit Chain. N.Y.: Free Press, 1997.

15. Ittner, C., Larcker, D., and Meyer, M. 2003, Subjectivity and the Weighting of Performance Measures: Evidence from a Balanced Scorecard. The Accounting Review.

16. Merchant, K. A. 1985. Control in Business Organizations. Cambridge, MA: Ballinger.

17. Merchant, K. A. \& Wim Van der Stede. 2007., 'Management Control Systems: Performance Measurement, Evaluation, and Incentives', London, Prentice Hall, Second Edition

18. Moers, F. 2006. Performance measure properties and delegation. The Accounting Review 81 (4): 897-924.

19. Nagar, V. 2002. Delegation and incentive compensation. The Accounting Review 77 (2): 379-395.

20. Prendergast, C. 2009. "Contracts and Conflict in Organizations," University of Chicago Working Paper. 
21. Prendergast, C. 2008. "Intrinsic Motivation and Incentives," American Economic Review: Papers \& Proceedings. 98(2): 201-205.

22. Simons, R. 2000. Performance Measurement and Control Systems for Implementing Strategy. Prentice Hall.

23. Van den Steen, Eric J. 2010. "Culture Clash: The Costs and Benefits of Homogeneity," Management Science (forthcoming). 
Figure 1: Evolution of Employee Selection Model

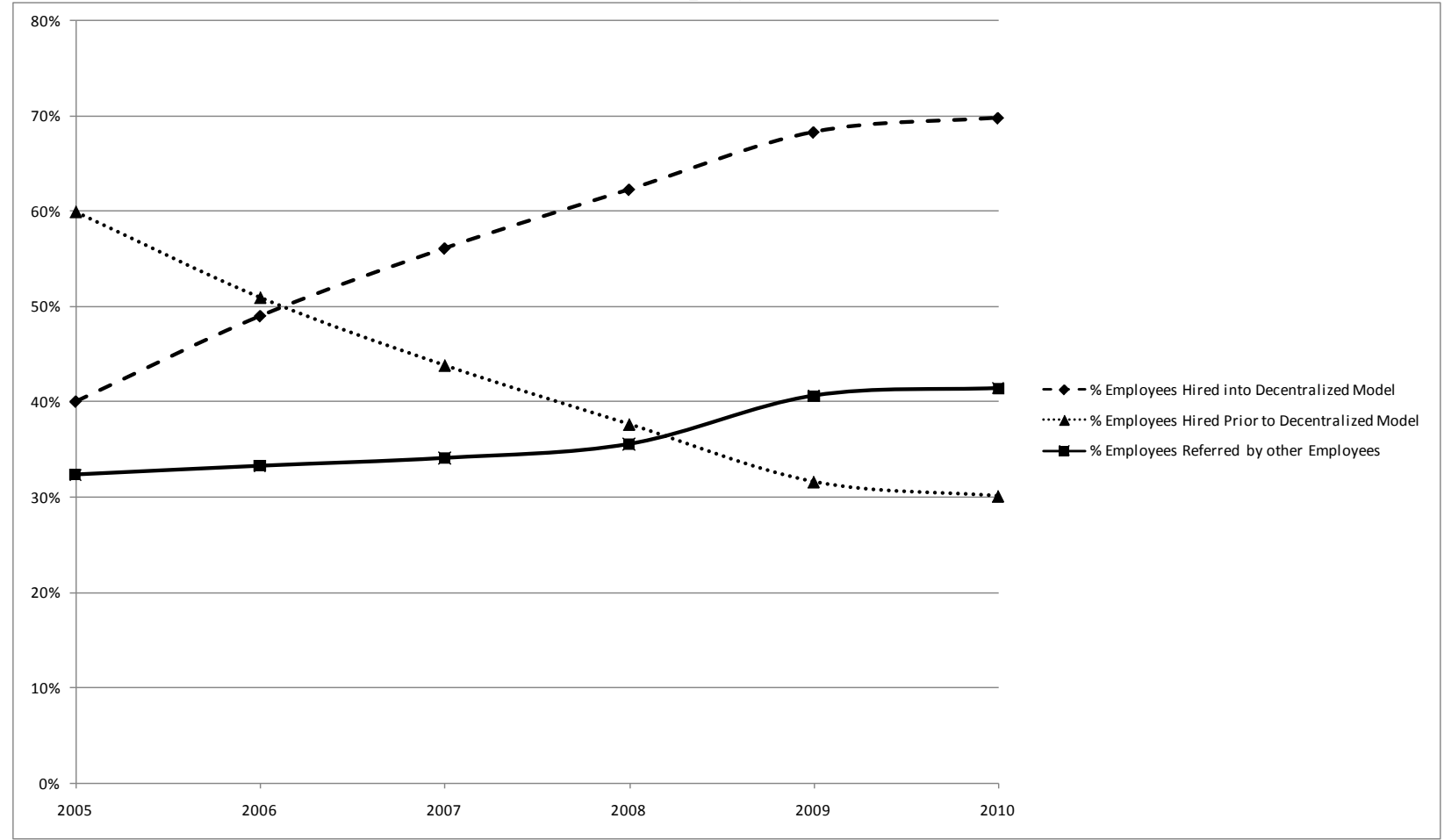

Figure 2: Concentration of Loan Decisions over Time

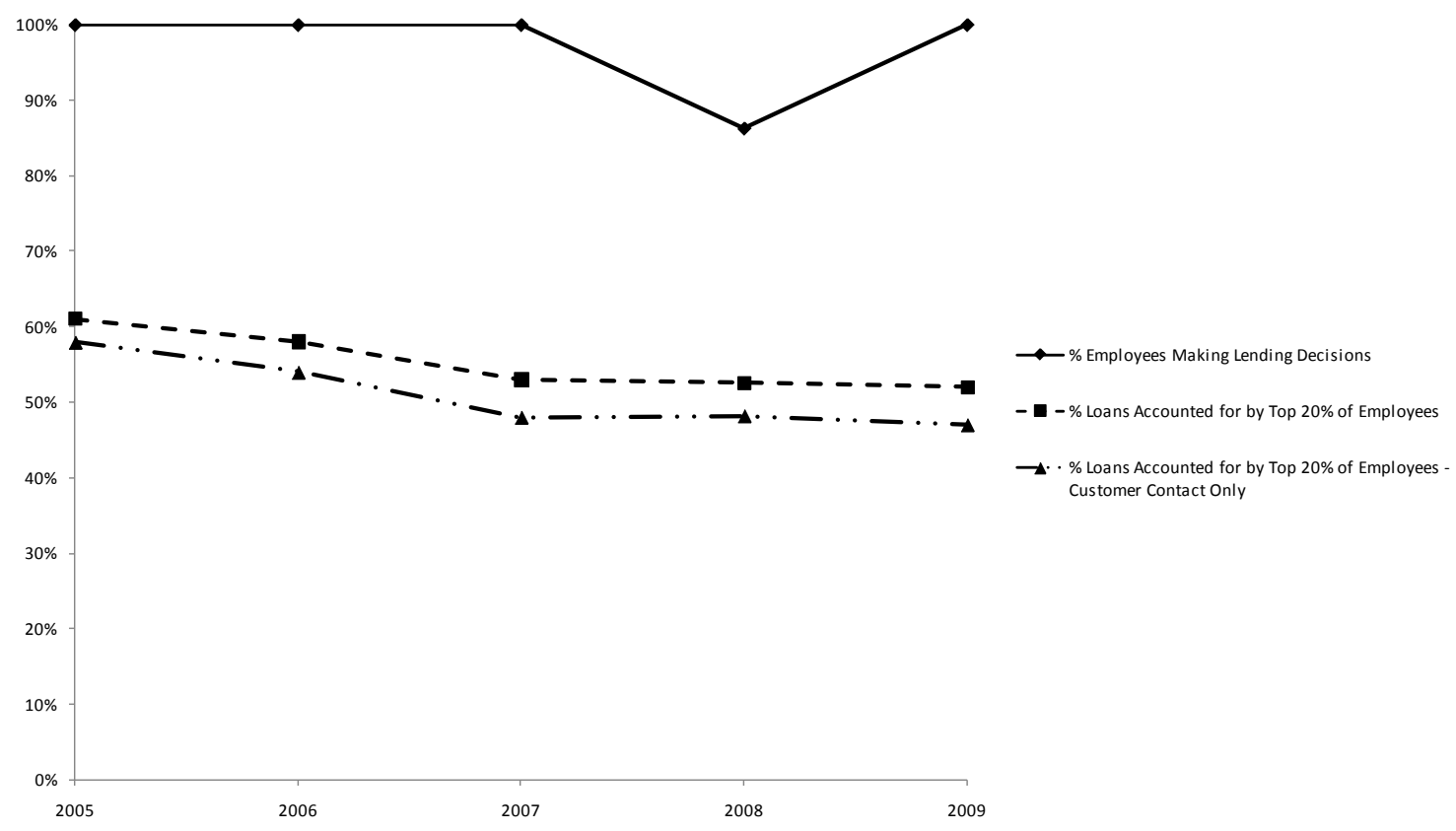


Figure 3: Distribution of Number of Loans per Employee per Year

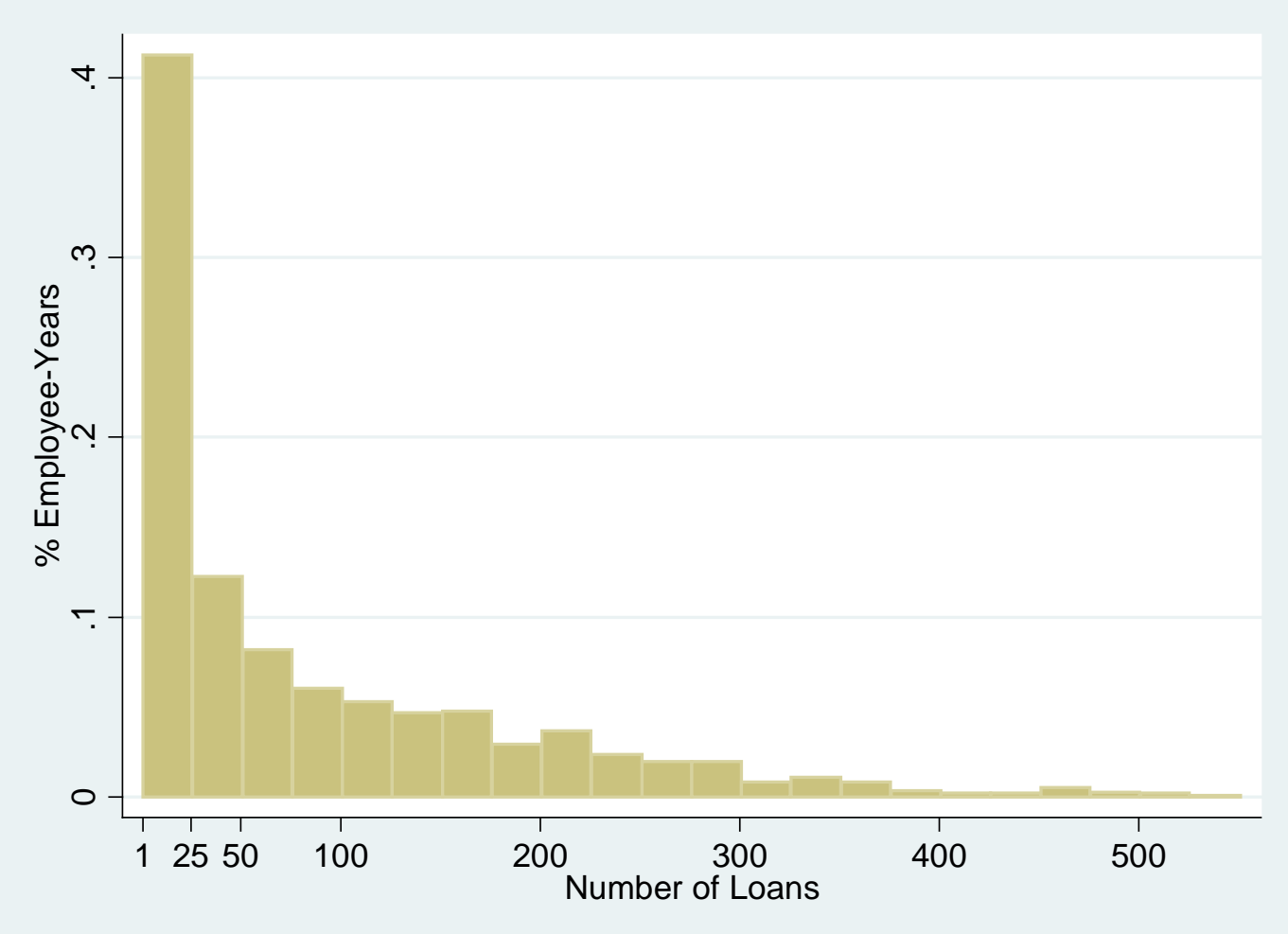

Figure 4: Loan Approval and Application Rates by System Rule Status

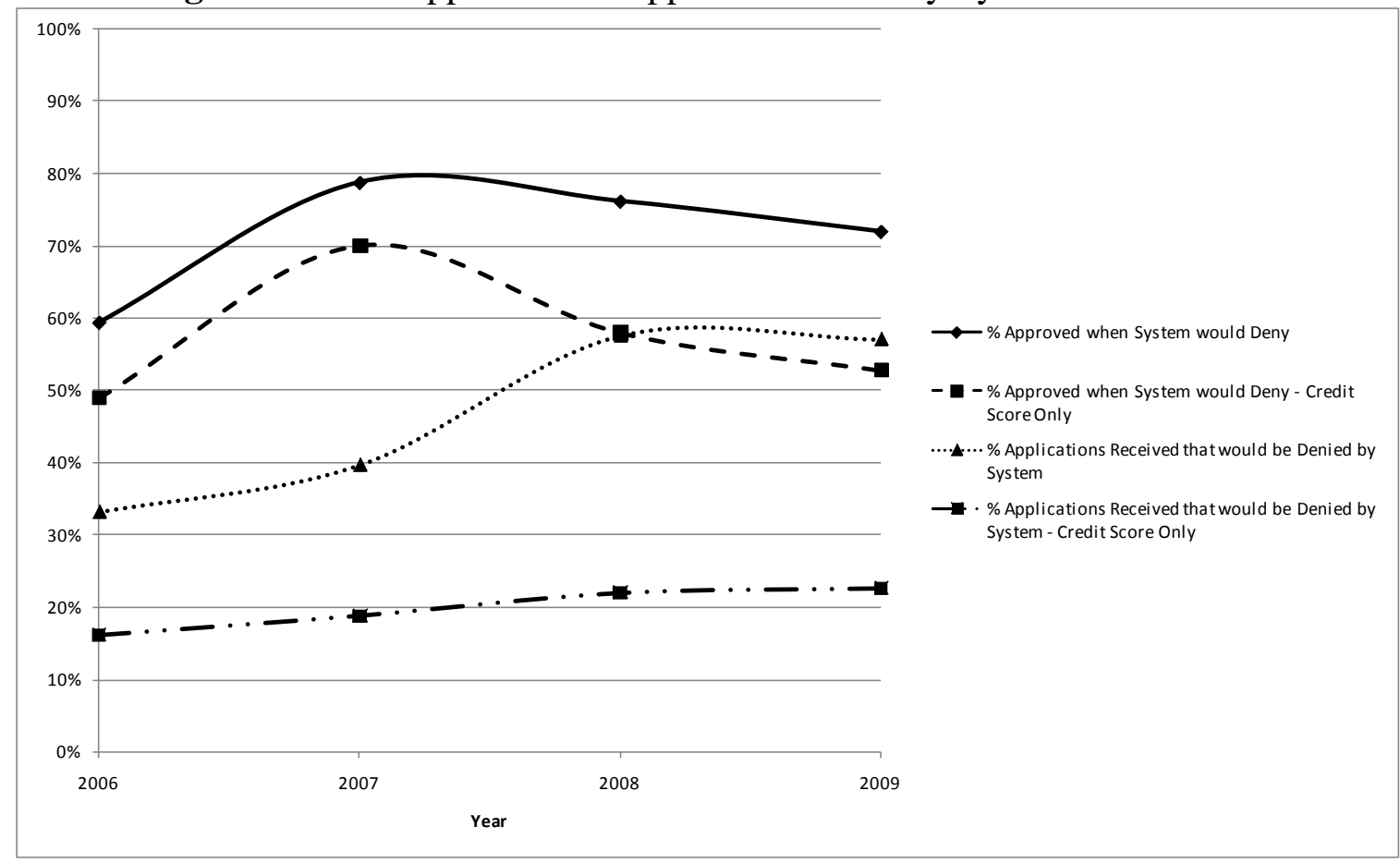


Table 1: Summary Statistics for Employee, Borrower, and Loan Characteristics

\begin{tabular}{|c|c|c|c|c|c|c|}
\hline Variables & $\begin{array}{c}\text { Sample Size and Unit of } \\
\text { Analysis }\end{array}$ & Mean & Median & $\begin{array}{l}\text { Std. } \\
\text { Dev. }\end{array}$ & Min & Max \\
\hline Employee Characteristics & Number Unique Employees & & & & & \\
\hline New System Employee, Referred by New System Employee & 463 & 0.08 & 0 & 0.27 & 0 & 1 \\
\hline New System Employee, Not Referred & 463 & 0.27 & 0 & 0.45 & 0 & 1 \\
\hline New System Employee, Referred by Old System Employee & 463 & 0.13 & 0 & 0.33 & 0 & 1 \\
\hline Old System Employee, Not Referred & 463 & 0.36 & 0 & 0.48 & 0 & 1 \\
\hline Old System Employee, Referred by Old System Employee & 463 & 0.16 & 0 & 0.37 & 0 & 1 \\
\hline Tenure in Organization (Years) & 463 & 4.21 & 3 & 4.75 & 0 & 32 \\
\hline$\underline{\text { Borrower Characteristics }}$ & Number Unique Borrowers & & & & & \\
\hline Credit Score & 64,540 & 710 & 720 & 74.59 & 393 & 836 \\
\hline Debt to Income Ratio & 64,540 & 37.92 & 34.94 & 21.86 & 0 & 200 \\
\hline$\underline{\text { Loan Characteristics }}$ & $\underline{\text { Number Unique Loans }}$ & & & & & \\
\hline Loan Amount & 134,121 & 13,519 & 9,000 & 18,865 & 25 & $2,371,200$ \\
\hline Interest Rate & 134,121 & 8.93 & 8.10 & 4.06 & 3 & 26 \\
\hline Term in Months & 134,121 & 318 & 55 & 67 & 0 & 581 \\
\hline Approved Loan has a Credit Score Exception & 134,121 & 0.13 & 0 & 0.33 & 0 & 1 \\
\hline Approved Loan has an Interest Rate Exception & 134,121 & 0.24 & 0 & 0.42 & 0 & 1 \\
\hline Loan Application Approved when System Rule would Deny (2007 only) & 13,637 & 0.73 & 1 & 0.35 & 0 & 1 \\
\hline $\begin{array}{l}\text { Prior Lending Experience of Employee up to Current Loan (\# past loans } \\
\text { made by employee) } \\
\text { Prior Customer-Specific Lending Experience of Employee up to Current }\end{array}$ & 134,121 & 360.71 & 254 & 341.45 & 0 & 1,752 \\
\hline Loan (\# past loans made by employee to a specific customer) & 134,121 & 1.35 & 0 & 0.92 & 0 & 20 \\
\hline
\end{tabular}

"New System" denotes employees hired after the organization’s implementation of its decentralized business model (post-2004); “Old System" denotes employees hired prior to the organization's implementation of its decentralized business model (2004 and earlier); summary statistics for employee characteristics are based on the pooled sample of employee-years from 2005-2009; summary statistics for borrower characteristics are based on the full sample of 134,121 loans; The minimum loan term of 0 is due to the presence of revolving credit lines such as credit cards and home equity lines of credit. 
Table 2: Summary Statistics and Distribution of Loans by Type

\begin{tabular}{|c|c|c|c|c|}
\hline Loan Type & $\begin{array}{c}\% \text { of All } \\
\text { Loans }\end{array}$ & Amount & Interest Rate & Term \\
\hline Secured Vehicle & $49 \%$ & $\$ 13,278$ & $6.88 \%$ & 61.24 \\
\hline Personal Line of Credit & 37 & 4,498 & 12.72 & 59.90 \\
\hline Mortgage and Home Equity & 14 & 36,654 & 6.39 & 114.72 \\
\hline
\end{tabular}


Table 3: Use of Decision-Making Authority by Employee Category

\begin{tabular}{|c|c|c|c|c|c|}
\hline & \multicolumn{5}{|c|}{ Employee Category } \\
\hline & $\begin{array}{l}\text { Old System } \\
\text { Referred by } \\
\text { Old System }\end{array}$ & $\begin{array}{l}\text { Old System not } \\
\text { Referred }\end{array}$ & $\begin{array}{l}\text { New System } \\
\text { Referred by } \\
\text { Old System }\end{array}$ & $\begin{array}{l}\text { New System } \\
\text { not Referred }\end{array}$ & $\begin{array}{l}\text { New System } \\
\text { Referred by } \\
\text { New System }\end{array}$ \\
\hline Number of Loans Approved 2005-2010 & 14,180 & 44,234 & 12,828 & 34,783 & 6,619 \\
\hline 2007 Approval Rate for System Denied Applicants & 71 & $75^{\mathrm{a}}$ & $76^{\mathrm{a}}$ & $77^{\mathrm{a}, \mathrm{b}}$ & $82^{\mathrm{a}, \mathrm{b}, \mathrm{c}, \mathrm{d}}$ \\
\hline \% Loans with Interest Rate Exceptions & 23 & 22 & $25^{\mathrm{a}, \mathrm{b}}$ & $26^{\mathrm{a}, \mathrm{b}, \mathrm{c}}$ & $29^{\mathrm{a}, \mathrm{b}, \mathrm{c}, \mathrm{d}}$ \\
\hline \multicolumn{6}{|l|}{ Corporate and Back Office Employees } \\
\hline 2007 Approval Rate for System Denied Applicants & 54 & 57 & 59 & $81^{\mathrm{a}, \mathrm{b}, \mathrm{c}}$ & $77^{\mathrm{a}, \mathrm{b}, \mathrm{c}}$ \\
\hline \% Loans with Interest Rate Exceptions & 18 & $23^{\mathrm{a}}$ & 20 & $26^{\mathrm{a}, \mathrm{b}, \mathrm{c}}$ & $21^{\mathrm{a}, \mathrm{d}}$ \\
\hline
\end{tabular}

“New System” denotes employees hired after the organization’s implementation of its decentralized business model (post-2004); “Old System” denotes employees hired prior to the organization's implementation of its decentralized business model (2004 and earlier); \% loans with credit score and interest rate exceptions are based on the full sample of 134,121 approved loans; "System Denied" refers to loan applications from applicants with credit scores less than 620 or debt to income ratios greater than 45\% or both; Approval rates for system denied loans are based only on loan applications received during 2007; a,b,c,d denote significantly different from old system-referred by old system, old system non referred, new system - referred by old system, and new system - non referred employees respectively at least at the $10 \%$ level based on two-sample tests of proportion 
Table 4: Loan Exception Logits

\begin{tabular}{|c|c|c|c|c|c|}
\hline Panel A: Customer Contact Employees & $\begin{array}{l}\text { Credit Score } \\
\text { Exception | } \\
\text { Approved } \\
\end{array}$ & $\begin{array}{l}\text { Credit Score } \\
\text { Exception | } \\
\text { Approved } \\
\end{array}$ & $\begin{array}{l}\text { Approve | System } \\
\text { would Deny (2007) }\end{array}$ & $\begin{array}{l}\text { Approve | System } \\
\text { would Deny - Credit } \\
\text { Score Only (2007) }\end{array}$ & $\begin{array}{l}\text { Interest Rate } \\
\text { Exception }\end{array}$ \\
\hline Prior Lending Experience & $\begin{array}{l}-0.0002 \\
(0.0004)\end{array}$ & $\begin{array}{l}-0.0002 \\
(0.0004)\end{array}$ & $\begin{array}{l}0.0009 \\
(0.0006)\end{array}$ & $\begin{array}{l}0.0008 \\
(0.0006)\end{array}$ & $\begin{array}{l}-0.0001 \\
(0.00007)\end{array}$ \\
\hline Prior Customer-Specific Lending Experience & $\begin{array}{l}0.059 * * * \\
(0.01)\end{array}$ & $\begin{array}{l}0.061^{* * *} \\
(0.01)\end{array}$ & $\begin{array}{l}0.24^{* *} \\
(0.10)\end{array}$ & $\begin{array}{l}0.28^{*} \\
(0.16)\end{array}$ & $\begin{array}{l}0.044^{* * *} \\
(0.01)\end{array}$ \\
\hline $\begin{array}{l}\text { Prior Year Average Credit Score for Loans made at } \\
\text { Business Unit }\end{array}$ & & $\begin{array}{l}-0.009 * * * \\
(0.00)\end{array}$ & & & \\
\hline Credit Grade A+ & & & $\begin{array}{l}1.667 * * * \\
(0.25)\end{array}$ & & $\begin{array}{l}-0.503^{* * *} \\
(0.03)\end{array}$ \\
\hline Credit Grade A & & & $\begin{array}{l}0.487 * * \\
(0.22)\end{array}$ & & $\begin{array}{l}0.02 \\
(0.04)\end{array}$ \\
\hline Credit Grade C & & & $\begin{array}{l}-1.018^{* * *} \\
(0.21)\end{array}$ & $\begin{array}{l}1.030^{* * *} \\
(0.17)\end{array}$ & $\begin{array}{l}0.340^{* * *} \\
(0.04)\end{array}$ \\
\hline Credit Grade D & & & $\begin{array}{l}-1.949 * * * \\
(0.18)\end{array}$ & & $\begin{array}{l}1.317 * * * \\
(0.03)\end{array}$ \\
\hline Debt to Income Ratio & & & $\begin{array}{l}-0.023 * * * \\
(0.002)\end{array}$ & $\begin{array}{l}-0.020 * * * \\
(0.002)\end{array}$ & $\begin{array}{l}0.00001^{* * *} \\
(0.000004)\end{array}$ \\
\hline Loan Amount (\$000’s) & $\begin{array}{l}-0.05^{* * *} \\
(0.005)\end{array}$ & $\begin{array}{l}-0.05^{* * *} \\
(0.006)\end{array}$ & $\begin{array}{l}-0.018^{* *} \\
(0.007)\end{array}$ & $\begin{array}{l}-0.010^{*} \\
(0.006)\end{array}$ & $\begin{array}{l}0.01^{* * *} \\
(0.001)\end{array}$ \\
\hline Old System Employee, Not Referred & $\begin{array}{l}0.035 \\
(0.04)\end{array}$ & $\begin{array}{l}0.031 \\
(0.04)\end{array}$ & $\begin{array}{l}0.262^{* *} \\
(0.13)\end{array}$ & $\begin{array}{l}0.337 * * \\
(0.15)\end{array}$ & $\begin{array}{l}-0.038 \\
(0.03)\end{array}$ \\
\hline New System Employee Referred by Old System & & & & & \\
\hline Employee & $\begin{array}{l}0.105^{*, \mathrm{~b}} \\
(0.06)\end{array}$ & $\begin{array}{l}0.127^{* *, b} \\
(0.06)\end{array}$ & $\begin{array}{l}0.391^{* *} \\
(0.17)\end{array}$ & $\begin{array}{l}0.507 * * * \\
(0.20)\end{array}$ & $\begin{array}{l}0.080^{*, b, c} \\
(0.04)\end{array}$ \\
\hline New System Employee, Not Referred & $\begin{array}{l}0.143^{* * *, b} \\
(0.05)\end{array}$ & $\begin{array}{l}0.131^{* * *, b} \\
(0.05)\end{array}$ & $\begin{array}{l}0.502^{* * *, b} \\
(0.13)\end{array}$ & $\begin{array}{l}0.548^{* * *, b} \\
(0.15)\end{array}$ & $\begin{array}{l}-0.052 \\
(0.03)\end{array}$ \\
\hline $\begin{array}{l}\text { New System Employee Referred by New System } \\
\text { Employee }\end{array}$ & $\begin{array}{l}0.385^{* * *, b, c, d} \\
(0.07)\end{array}$ & $\begin{array}{l}0.326 * * *, b, c, d \\
(0.07)\end{array}$ & $\begin{array}{l}1.776 * * *, b, c, d \\
(0.42)\end{array}$ & $\begin{array}{l}1.697 * * *, \mathrm{~b}, \mathrm{c}, \mathrm{d} \\
(0.48)\end{array}$ & $\begin{array}{l}0.104^{*, \mathrm{~b}, \mathrm{c}} \\
(0.06)\end{array}$ \\
\hline Constant & $\begin{array}{l}-0.727 * * * \\
(0.19)\end{array}$ & $\begin{array}{l}5.688^{* * * *} \\
(0.44)\end{array}$ & $\begin{array}{l}20.344 \\
(0.35)\end{array}$ & $\begin{array}{l}19.081^{* * *} \\
(0.40)\end{array}$ & $\begin{array}{l}-3.218^{* * *} \\
(0.14)\end{array}$ \\
\hline Observations & 112,997 & 93,751 & 10,052 & 4,623 & 112,997 \\
\hline
\end{tabular}




\begin{tabular}{|c|c|c|c|c|c|}
\hline $\begin{array}{l}\text { Panel B: Corporate and Back Office } \\
\text { Employees }\end{array}$ & $\begin{array}{l}\text { Credit Score } \\
\text { Exception | } \\
\text { Approved }\end{array}$ & $\begin{array}{l}\text { Credit Score Exception | } \\
\text { Approved }\end{array}$ & $\begin{array}{l}\text { Approve | System } \\
\text { would Deny (2007) }\end{array}$ & $\begin{array}{l}\text { Approve | System } \\
\text { would Deny - Credit } \\
\text { Score Only (2007) }\end{array}$ & $\begin{array}{l}\text { Interest Rate } \\
\text { Exception }\end{array}$ \\
\hline Prior Lending Experience & $\begin{array}{l}-0.0006^{* *} \\
(0.0003)\end{array}$ & $\begin{array}{l}-0.0006^{* *} \\
(0.0003)\end{array}$ & $\begin{array}{l}0.002 \\
(0.0017)\end{array}$ & $\begin{array}{l}-0.001 \\
(0.89)\end{array}$ & $\begin{array}{l}-0.0003 \\
(0.0002)\end{array}$ \\
\hline Prior Customer-Specific Lending Experience & $\begin{array}{l}0.02 \\
(0.03)\end{array}$ & $\begin{array}{l}0.03 \\
(0.03)\end{array}$ & $\begin{array}{l}-0.72 \\
(0.59)\end{array}$ & $\begin{array}{l}-0.86 \\
(0.58)\end{array}$ & $\begin{array}{l}0.089 * * * \\
(0.02)\end{array}$ \\
\hline $\begin{array}{l}\text { Prior Year Average Credit Score for Loans } \\
\text { made at Business Unit }\end{array}$ & & $\begin{array}{l}-0.008 * * * \\
(0.00)\end{array}$ & & & \\
\hline Credit Grade A+ & & & $\begin{array}{l}1.061^{* * *} \\
(0.34)\end{array}$ & & $\begin{array}{l}-0.670^{* * *} \\
(0.06)\end{array}$ \\
\hline Credit Grade A & & & $\begin{array}{l}0.841^{* *} \\
(0.35)\end{array}$ & & $\begin{array}{l}0.025 \\
(0.09)\end{array}$ \\
\hline Credit Grade C & & & $\begin{array}{l}-1.549 * * * \\
(0.35)\end{array}$ & $\begin{array}{l}1.554^{* * *} \\
(0.36)\end{array}$ & $\begin{array}{l}0.204^{* *} \\
(0.10)\end{array}$ \\
\hline Credit Grade D & & & $\begin{array}{l}-2.723^{* * *} \\
(0.30)\end{array}$ & & $\begin{array}{l}1.051^{* * *} \\
(0.08)\end{array}$ \\
\hline Debt to Income Ratio & & & $\begin{array}{l}-0.031^{* * *} \\
(0.004)\end{array}$ & $\begin{array}{l}-0.029 * * * \\
(0.00)\end{array}$ & $\begin{array}{l}0.000003^{* * *} \\
(0.000001)\end{array}$ \\
\hline Loan Amount (\$000's) & $\begin{array}{l}-0.03 \\
(0.008)\end{array}$ & $\begin{array}{l}-0.03 \\
(0.008)\end{array}$ & $\begin{array}{l}-0.004 \\
(0.17)\end{array}$ & $\begin{array}{l}0.03 \\
(0.02)\end{array}$ & $\begin{array}{l}0.003^{* * *} \\
(0.00)\end{array}$ \\
\hline Old System Employee, Not Referred & $\begin{array}{l}0.288^{* * *} \\
(0.11)\end{array}$ & $\begin{array}{l}0.236^{* *} \\
(0.11)\end{array}$ & $\begin{array}{l}0.158 \\
(0.22)\end{array}$ & $\begin{array}{l}0.277 \\
(0.29)\end{array}$ & $\begin{array}{l}0.096 \\
(0.07)\end{array}$ \\
\hline New System Employee Referred by Old & & & & & \\
\hline System Employee & $\begin{array}{l}0.166 \\
(0.18)\end{array}$ & $\begin{array}{l}0.169 \\
(0.18)\end{array}$ & $\begin{array}{l}0.725^{* *} \\
(0.29)\end{array}$ & $\begin{array}{l}0.828 * * \\
(0.35)\end{array}$ & $\begin{array}{l}-0.125 \\
(0.14)\end{array}$ \\
\hline New System Employee, Not Referred & $\begin{array}{l}0.510^{* * *} \\
(0.14)\end{array}$ & $\begin{array}{l}0.462 * * * \\
(0.14)\end{array}$ & $\begin{array}{l}0.058 \\
(0.54)\end{array}$ & $\begin{array}{l}-0.401 \\
(0.67)\end{array}$ & $\begin{array}{l}0.061 \\
(0.09)\end{array}$ \\
\hline New System Employee Referred by New & & & & & \\
\hline System Employee & $\begin{array}{l}0.629 * * * \\
(0.18)\end{array}$ & $\begin{array}{l}0.570^{* * *} \\
(0.18)\end{array}$ & $\begin{array}{l}0.444 \\
(0.78)\end{array}$ & $\begin{array}{l}1.097 \\
(0.87)\end{array}$ & $\begin{array}{l}-0.382^{* * *} \\
(0.13)\end{array}$ \\
\hline Constant & $\begin{array}{l}0.222 \\
(1.28)\end{array}$ & $\begin{array}{l}4.332 * * * \\
(1.50)\end{array}$ & $\begin{array}{l}25.328^{* * *} \\
(1.53)\end{array}$ & $\begin{array}{l}22.815^{* * *} \\
(1.68)\end{array}$ & $\begin{array}{l}-3.104^{* * *} \\
(0.29)\end{array}$ \\
\hline Observations & 21,124 & 17,526 & 3,585 & 1,476 & 21,124 \\
\hline
\end{tabular}

Standard errors corrected for clustering within employees in parentheses; *,**,*** significant at 10\%, 5\%, $1 \%$ levels respectively; b,c,d significantly different from old system non referred, new system - referred by old system, and new system - non referred employees respectively at least at the $10 \%$ level based on chi-square tests; business unit, year, and loan type indicators included in all specifications. "New System” denotes employees hired after the organization's implementation of its decentralized business model (post- 
2004); “Old System” denotes employees hired prior to the organization’s implementation of its decentralized business model (2004 and earlier); “System Denied” refers to loan applications from applicants with credit scores less than 620 or debt to income ratios greater than $45 \%$ or both; "System Denied - Credit Score Only" refers to loan applications from applicants with credit scores less than 620 without consideration of debt to income ratio; The dependent variable in the column labeled "Credit Score Exception | Approved" is an indicator for whether an approved loan is one for which a credit score exception was made in the approval process; The dependent variable in the column labeled "Approve | System would Deny” is an indicator for whether a loan application is approved when the system rule based on credit score and debt-to-income ratio would deny the loan; Approval rates for system denied loans are based only on loan applications received during 2007; The dependent variable in the column labeled "Interest Rate Exception" is an indicator for whether the actual interest rate is different than the organization's standard interest rate given the characteristics of the loan and borrower. The excluded category for "Credit Grade” is 'B' in all specifications except for the column labeled “Approve | System would Deny - Credit Score Only” where the excluded category is Credit Grade = 'D'. 
Table 5: Charge-Off Rates by System Rule Status and Employee Category

\begin{tabular}{|c|c|c|}
\hline & \multicolumn{2}{|c|}{ Charge-Off Rates for Loans: } \\
\hline & $\begin{array}{l}\text { Meeting System } \\
\text { Criteria }\end{array}$ & $\begin{array}{l}\text { Not Meeting } \\
\text { System Criteria }\end{array}$ \\
\hline Average & $0.40 \%$ & $1.9 \%{ }^{*}$ \\
\hline \multicolumn{3}{|l|}{ By Employee Category: } \\
\hline Old System, Referred by Old System & $0.30 \%$ & $2.49 \%{ }^{*}$ \\
\hline Old System, Not Referred & $0.64 \%$ & $2.19 \%^{*}$ \\
\hline New System, Referred by Old System & $0.41 \%$ & $2.17 \%^{*}$ \\
\hline New System, not Referred & $0.60 \%$ & $1.48 \%^{*, b, c, d}$ \\
\hline New System, Referred by New System & $0.54 \%$ & $0.77 \%^{a, b, c, d}$ \\
\hline \multicolumn{3}{|c|}{$\begin{array}{l}\text { * denotes mean charge-off rates are significantly different from those for loans meeting system criteria } \\
\text { at less than the } 1 \% \text { level; where the asterisk is absent, this difference is not statistically significant at at system, } \\
\text { least at the } 10 \% \text { level; a,b,c,d denotes significantly different from old system-referred by old system, } \\
\text { old system - non referred, new system - referred by old system, and new system - non referred } \\
\text { employees respectively at least at the } 10 \% \text { level based on two-sample tests of proportion; Charge-off } \\
\text { rates are calculated based on loans funded during } 2007 \text { and } 2008 \text { that were charged off within } 18 \\
\text { months. "New System" denotes employees hired after the organization's implementation of its } \\
\text { decentralized business model (post-2004); "Old System" denotes employees hired prior to the } \\
\text { organization's implementation of its decentralized business model (2004 and earlier) }\end{array}$} \\
\hline
\end{tabular}


Table 6: Charge-Off Logits

\begin{tabular}{|c|c|c|c|c|}
\hline & \multicolumn{2}{|c|}{ Customer Contact Employees } & \multicolumn{2}{|c|}{ All Employees } \\
\hline & System Denied & $\begin{array}{l}\text { System Denied - } \\
\text { Credit Score Only }\end{array}$ & System Denied & $\begin{array}{l}\text { System Denied - } \\
\text { Credit Score Only }\end{array}$ \\
\hline Credit Grade A+ & $\begin{array}{l}-1.133^{* * *} \\
(0.43)\end{array}$ & & $\begin{array}{l}-0.317 \\
(0.29)\end{array}$ & \\
\hline Credit Grade A & $\begin{array}{l}-0.537^{*} \\
(0.30)\end{array}$ & & $\begin{array}{l}-0.265 \\
(0.34)\end{array}$ & \\
\hline Credit Grade C & $\begin{array}{l}1.322^{* * *} \\
(0.28)\end{array}$ & $\begin{array}{l}-0.515^{* * *} \\
(0.18)\end{array}$ & $\begin{array}{l}1.449^{* * *} \\
(0.27)\end{array}$ & $\begin{array}{l}-0.717^{* * *} \\
(0.17)\end{array}$ \\
\hline Credit Grade D & $\begin{array}{l}1.377^{* * *} \\
(0.26)\end{array}$ & & $\begin{array}{l}1.722^{* * *} \\
(0.25)\end{array}$ & \\
\hline Debt to Income Ratio & $\begin{array}{l}-0.003 \\
(0.003)\end{array}$ & $\begin{array}{l}-0.006 \\
(0.004)\end{array}$ & $\begin{array}{l}0.00004 \\
(0.00007)\end{array}$ & $\begin{array}{l}0.0005 \\
(0.0008)\end{array}$ \\
\hline Loan Amount (\$000’s) & $\begin{array}{l}-0.003 \\
(0.02)\end{array}$ & $\begin{array}{l}-0.04^{* *} \\
(0.02)\end{array}$ & $\begin{array}{l}0.004 \\
(0.01)\end{array}$ & $\begin{array}{l}-0.02 \\
(0.24)\end{array}$ \\
\hline Old System Employee, Not Referred & $\begin{array}{l}-0.192 \\
(0.15)\end{array}$ & $\begin{array}{l}-0.168 \\
(0.16)\end{array}$ & $\begin{array}{l}-0.410^{* * *} \\
(0.13)\end{array}$ & $\begin{array}{l}-0.424^{* * *} \\
(0.14)\end{array}$ \\
\hline New System Employee Referred by Old & & & & \\
\hline System Employee & $\begin{array}{l}-0.257 \\
(0.18)\end{array}$ & $\begin{array}{l}-0.145 \\
(0.19)\end{array}$ & $\begin{array}{l}-0.433^{* * *} \\
(0.16)\end{array}$ & $\begin{array}{l}-0.310^{*} \\
(0.18)\end{array}$ \\
\hline New System Employee, Not Referred & $\begin{array}{l}-0.383^{* * *, b, c} \\
(0.15)\end{array}$ & $\begin{array}{l}-0.605^{* * *, b, c} \\
(0.17)\end{array}$ & $\begin{array}{l}-0.450^{* * *} \\
(0.12)\end{array}$ & $\begin{array}{l}-0.594^{* * *, c} \\
(0.14)\end{array}$ \\
\hline $\begin{array}{l}\text { New System Employee Referred by New } \\
\text { System Employee }\end{array}$ & $\begin{array}{l}-2.249^{* * *, b, c, d} \\
(0.59)\end{array}$ & $\begin{array}{l}-2.527^{* * *, b, c, d} \\
(0.72)\end{array}$ & $\begin{array}{l}-2.294^{* * *, b, c, d} \\
(0.46)\end{array}$ & $\begin{array}{l}-2.377^{* * *, b, c, d} \\
(0.52)\end{array}$ \\
\hline Constant & $\begin{array}{l}-2.624^{* * *} \\
(0.35)\end{array}$ & $\begin{array}{l}-1.236^{* * *} \\
(0.25)\end{array}$ & $\begin{array}{l}-2.932^{* * *} \\
(0.31)\end{array}$ & $\begin{array}{l}-1.261^{* * *} \\
(0.21)\end{array}$ \\
\hline Observations & 18,779 & 7,016 & 22,356 & 8,352 \\
\hline
\end{tabular}

Standard errors in parentheses; *,**,** significant at 10\%, 5\%, $1 \%$ levels respectively; b,c,d significantly different from old system-referred by old system, old system - non referred, new system - referred by old system, and new system - non referred employees respectively at least at the $10 \%$ level based on two-sample tests of proportion; Charge-off rates are calculated based on loans funded during 2007 and 2008 that were charged off within 18 months. "System Denied" denotes the sample of loans made to borrowers with either credit scores less than 620 or debt to income ratios greater than 45\%. "System Denied - Credit Score Only" denotes the sample of loans made to borrowers with credit scores less than 620 without consideration of the debt-to-income ratio. 


\section{Appendix A: Random Sample of 20 Employee Comments on the Use of Decision- Making Authority}

\begin{tabular}{|c|c|}
\hline $\begin{array}{l}\text { Employee } \\
\text { Comment }\end{array}$ & $\begin{array}{l}\text { An employee comes to you with a member situation that, if the decision is made to go } \\
\text { ahead with the request, will require working "outside the box." What advice would give } \\
\text { the employee on decision making and execution? }\end{array}$ \\
\hline 1 & $\begin{array}{l}\text { Consider what the member is requesting first and foremost and make sure what direction } \\
\text { we are taking it fulfills the request. Always suggest partnership with their direct leader to } \\
\text { get their perspective on the route taken. Also don't be afraid to utilize other resources } \\
\text { around them as well. Then make sure we have looked/considered alternatives and that } \\
\text { this is the best route all things considered. Make sure we understand the pros/cons of the } \\
\text { choice for us to make this decision in how it affects [the organization]. I just feel } \\
\text { exceptions are a great thing but we always need to acknowledge what we are risking with } \\
\text { the exception after consideration to how the member is served by our choice/exception. } \\
\text { Make sure the member understands all the pros and cons of the direction we are going } \\
\text { and that this is their choice for meeting their financial goals. Then set up some reminders } \\
\text { to make sure everything is executed as intended and the member is informed about } \\
\text { where things are at }\end{array}$ \\
\hline 2 & $\begin{array}{l}\text { Depending on what we are doing, I would first ask if the member is a Participating } \\
\text { member. Tell me a little bit about the relationships we have with them. How will this } \\
\text { affect the member and then organization? Why do you think this is the right thing to do? I } \\
\text { would encourage outside the box thinking what is the members ultimate goal and how } \\
\text { can we help get them there? }\end{array}$ \\
\hline 3 & $\begin{array}{l}\text { You always want to put the member first, and start with M.O.E. I would advise asking the } \\
\text { following questions; "Is this right for the member?", "Will it cause success for them?" If } \\
\text { you answer "yes" to these questions, you are empowered to and should do what is } \\
\text { necessary for that specific members need. Doing what is truly right for someone will build } \\
\text { trust and a relationship will blossom }\end{array}$ \\
\hline 4 & $\begin{array}{l}\text { I would first try and understand if the employee had gotten to know the member and } \\
\text { truly understands their goals. Sometimes, I find that employee's get carried away with } \\
\text { wanting to go 'above and beyond" without realizing that what the member truly wants is } \\
\text { a much simpler solution and already available and supported by our strategy and products } \\
\text { as in- for example the PR rewards program for refunding fee's or making rate exceptions. } \\
\text { Other times, employees can get "bullied" into making an out of the box decision because } \\
\text { a member "demands" it. This is hard for employees to resist because they know that they } \\
\text { CAN make what the member is demanding happen and that they could tell themselves } \\
\text { and the organization that they had simply "used their empowerment" to make an } \\
\text { exception for the member. This is NOT building relationships founded on trust with a } \\
\text { member, rather the opposite. } \\
\text { However, if an employee can articulate that they have really gotten to the heart of the } \\
\text { members goal and the solution is beyond what we currently offer I would encourage the } \\
\text { employee to make the commitment to the member and "worry" about how we were } \\
\text { going to make it happen on the back end. There are some limitations to this of course, but } \\
\text { if the goal is reasonable, or within the field of possibility- in other words not something } \\
\text { like, "I want to buy a house, but I have no money down and no credit and I can't afford to } \\
\text { pay more than \$50 a month." } \\
\text { We have tremendous resources that we can tap to make the impossible possible if it is } \\
\text { right for the member and contributes to their financial success in a meaningful way- not } \\
\text { just addressing a "demand" for service per se, but rather being creative in eliminating } \\
\text { assumptions about barriers and reaching a positive outcome through thinking differently } \\
\text { rather than forcing a member into a box. It is also important, I believe, when making the } \\
\text { commitment to the member, that we are clear that we are going to do everything }\end{array}$ \\
\hline
\end{tabular}




\begin{tabular}{|c|c|}
\hline & $\begin{array}{l}\text { possible to creatively make their goal a reality, but that it might not look exactly like they } \\
\text { want it to- but will hopefully address their ultimate goal. For example, a member may } \\
\text { want to buy his girlfriend an engagement ring, but the ring he wants is too expensive for } \\
\text { him to feasibly afford at this time. But, he knows it's the ring for her and he will do just } \\
\text { about anything to make it work. If we have spent time with this member, understand his } \\
\text { intentions and believe in his ultimate ability to take on the debt and his commitment and } \\
\text { relationship with us is such that we believe he will WANT to pay us back ( this is the } \\
\text { relationship part- the reciprocal commitment us to member and member to us), we might } \\
\text { extend a signature loan term to } 7 \text { years or we might know that there is a local jeweler } \\
\text { who is also a member that can make the same ring the member saw in a department } \\
\text { store for half the price, or we might see if we can help the member budget such that he } \\
\text { saves some of the money to pay for the ring up front and then we write a signature loan } \\
\text { for the remaining... the possibilities are endless. }\end{array}$ \\
\hline 5 & $\begin{array}{l}\text { First I would ask them what the impact to the member is? How is this going to affect the } \\
\text { member? Then I would ask them if this is a long term solution or short term. } \\
\text { Understanding the goals of the member, and the full impact of the loan decision will help } \\
\text { guide the member advisor as to if this loan is going to benefit the member in a positive } \\
\text { way. If we can help our members not only short term, but also long term, we will begin to } \\
\text { solidify the relationship with the member, and build a deeper foundation of trust }\end{array}$ \\
\hline 6 & $\begin{array}{l}\text { The most important thing to consider is to ensure this is setting the member up for future } \\
\text { success - a creative solution is great, but if it's going to add to problems down the road } \\
\text { we need to keep looking for more solutions. Also, when you are working "outside the } \\
\text { box" you are making the commitment to follow up on your creative solution to ensure } \\
\text { that it is working the way it's intended. Empowerment comes with responsibility and it's } \\
\text { great to be able to create a solution but you must commit to ensuring that solution works } \\
\text { and following up with that member on a regular basis. This is a vital part of Building } \\
\text { Relationships founded on Trust because if we come up with a great solution, but fall down } \\
\text { on the execution or just drop the plan after it's put into place, the member is going to lose } \\
\text { faith }\end{array}$ \\
\hline 7 & $\begin{array}{l}\text { I would advise the employee to hold the member accountable and follow up with the } \\
\text { member to assure success. Set goals that are realistic for the members so they can } \\
\text { succeed and then slowly tighten up goals once they show they are commited and having } \\
\text { success with plan. Also by working outside the box we need to consider the } \\
\text { organization/other members risk when we are making decision }\end{array}$ \\
\hline 8 & $\begin{array}{l}\text { Think about: What kind of relationship does the member have with [the organization]? Do } \\
\text { they use us as their primary financial? What is the surrounding situation and story in } \\
\text { relation to what they are requesting from [the organization]? Instead of the quick fix, } \\
\text { think long term and if our initial diagnosis of their situation and the solution we come up } \\
\text { with is in the member's best interest several years from now? }\end{array}$ \\
\hline 9 & $\begin{array}{l}\text { There's no true definition of "outside the box"-it could be taking a leap of faith on a } \\
\text { member who on paper has a rocky past, but in talking to them you find they had some } \\
\text { medical issues or a divorce that took a toll on finances. Outside the box could also mean } \\
\text { an idea that's totally out there-a traveling credit union (think book-mobile) or driving to } \\
\text { a member's house to close a mortgage. Regardless of the situation, I would offer the } \\
\text { advice to my co-worker to get to know the member-ask them questions, find out what is } \\
\text { important to them, and ask how they would like to proceed. When you're throwing } \\
\text { around ideas, don't think first about the organization and what will happen to you-think } \\
\text { about the MEMBER-how what you're wanting help them and what you're willing to do, } \\
\text { and the organization will follow. }\end{array}$ \\
\hline 10 & $\begin{array}{l}\text { They can't be afraid to ask the tough questions of the member and their situation. If we } \\
\text { don't do that and just become order takers and fulfillers we are not setting the member } \\
\text { up for long term financial success. We need to understand why this solution makes sense }\end{array}$ \\
\hline
\end{tabular}




\begin{tabular}{|c|c|}
\hline & $\begin{array}{l}\text { for their situation. Why is this the right solution and how does this ensure that it not only } \\
\text { sets them up for success in this moment but also for future success? }\end{array}$ \\
\hline 11 & $\begin{array}{l}\text { I think you can run any "outside the Box" situation through MOE to help with your } \\
\text { answer. We, as employees of [the organization] have been given a gift and that gift is } \\
\text { empowerment. Empowerment is where we have the opportunity to step out of the } \\
\text { guidelines and make it work for our member. Building relationships founded on trust goes } \\
\text { both ways, the member trusts that we will do what is right for them and we trust that the } \\
\text { member will in turn do what we have asked them to. }\end{array}$ \\
\hline 12 & $\begin{array}{l}\text { My advice in decision making is to strongly encourage the employee to filter the thought } \\
\text { process through MOE. Then, document like there is no tomorrow. The documenting } \\
\text { should include thought process of everything considered - whether rejected or not. The } \\
\text { member should be brought through the thinking process with the employee to ensure we } \\
\text { are providing an outcome the member actually desires }\end{array}$ \\
\hline 13 & $\begin{array}{l}\text { I feel that here there is no box, so I don't feel I really ever work outside of it. I have held } \\
\text { firm in that if we do what we feel is right for the member the organization will be behind } \\
\text { us } 100 \% \text {. In terms of the member the execution depends on the relationship that you } \\
\text { create in your interaction. }\end{array}$ \\
\hline 14 & $\begin{array}{l}\text { Listen to the need and the want, common sense, being honest, and filter MOE, looking at } \\
\text { the short term and long term for the member. Making the member smart, when you start } \\
\text { and finish the process or follow up with the member to confirm with information and a } \\
\text { direct name and number to reach back to, make notes in Touché. }\end{array}$ \\
\hline 15 & $\begin{array}{l}\text { When employees come to me for advice regarding a decision that needs to made out-side } \\
\text { the box I stress that the decision and follow through should be based off the member. } \\
\text { When thinking out-side the box and transacting business differently for a member the } \\
\text { communication and the follow up absolutely needs to be there } 100 \% \text {. These variables are } \\
\text { extremely important in any transaction but even more so in situations that are sculpted } \\
\text { specifically for certain members. In these types of scenario's the communication needs to } \\
\text { be very thorough with our members as well as within the organization so every person } \\
\text { involved or anyone stepping in knows how to transact business. These situations should } \\
\text { be closely monitored also not only to ensure the member understands and so that it is } \\
\text { smooth for them but also to ensure that the member is holding up there end of the deal. I } \\
\text { tend to give the hand holding comparison when thinking out of the box. I find that holding } \\
\text { our members hands when they are willing to fulfill their end of deal is very successful in } \\
\text { building a relationship on trust and then when they don't hold up their end of the bargain } \\
\text { I get a better picture of the relationship we have }\end{array}$ \\
\hline 16 & $\begin{array}{l}\text { In "outside the box" thinking, two overall factors come to the surface regarding this issue. } \\
\text { The first filter of the two pertains to making sure that what is being proposed, is within } \\
\text { the regulatory and legal parameters. Once a proposed course of action passes this first } \\
\text { criterion, the next step would be to then run this decision past the filter of M.O.E. Given } \\
\text { our operational culture, M.O.E. should not be considered outside the box; however it is } \\
\text { through this filter that we ensure that we stay true to the proper course of action without } \\
\text { the rigid guardrails of procedure. }\end{array}$ \\
\hline 17 & $\begin{array}{l}\text { In engaging the employee I feel that it would be beneficial to remind the employee to not } \\
\text { get too caught up in procedure until the direction has been determined. I have often } \\
\text { received calls from other member advisors regarding the procedures that assist our } \\
\text { members in the completion of a voluntary repossession; and what I find is that their } \\
\text { concentration and attention is focused upon learning and completing the action itself, } \\
\text { then we fail to make the connection to truly understand why a member would be looking } \\
\text { at surrendering their auto in the first place. My point being is that my advice to that } \\
\text { member advisor would be ensure that they run the decision through M.O.E. prior to } \\
\text { worrying about how they are going to get there. With the M of M.O.E. I would suggest to } \\
\text { the member advisor that they begin with the end in mind, meaning that given the }\end{array}$ \\
\hline
\end{tabular}




\begin{tabular}{|c|c|}
\hline & $\begin{array}{l}\text { member's current goal and means to achieve this goal, where would they ultimately end } \\
\text { up and what would that look like. Following up with a reasonable assessment of how the } \\
\text { attainment of this goal would impact their overall financial picture. Granted this is a very } \\
\text { basic description but I feel it can be easily overlooked if their initial direction conflicts with } \\
\text { a standard procedure or way we typically do things. The goal would be to start with the } \\
\text { perspective of the member by being a member advocate first, prior to then running it past } \\
\text { the filter of } O \text { in M.O.E. While simultaneously determining where things are at from the } \\
\text { member's perspective one would likely be also laying the foundation for a relationship } \\
\text { founded upon trust. The skills and actions required, (empathy, active listening, etc.), to } \\
\text { understand the position of the member are also the skills required to cultivate trust in the } \\
\text { member/member advisor relationship. I feel that a relationship founded on trust starts } \\
\text { with an empathetic and focused ear on what is being said by the member before we } \\
\text { charge forward with a proposed action. }\end{array}$ \\
\hline 18 & $\begin{array}{l}\text { If I were approached by a coworker facing this situation, I would first ask him/her the way } \\
\text { he/she wants to proceed and the reasons he/she believes that is the right thing to do for } \\
\text { the member, the organization, and the employee. I believe that doing so challenges all of } \\
\text { us to be better for the member, encourages us to grow and believe in ourselves and our } \\
\text { ability to serve the member, and causes us to take full ownership of the situation and the } \\
\text { outcome for the member. I also think it helps avoid becoming the single point of decision } \\
\text { making that an employee comes to depend on. Not to mention, our gut reaction generally } \\
\text { offers the best advice. Upon hearing his/her response, I would likely challenge my peer as } \\
\text { well. I might challenge him/her to think differently about his/her decision-making } \\
\text { process, asking questions and providing ideas that use the decision-making filer, MOE. I } \\
\text { might challenge him/her to share the way he/she intends to use empowerment to create } \\
\text { a meaningful experience for the member and help him/her brainstorm creative ideas. I } \\
\text { might challenge the employee to think differently about follow-up with the member to } \\
\text { ensure they are building the relationship with the member overtime, rather than closing } \\
\text { the door and waiting for the member to come back to us in the future }\end{array}$ \\
\hline 19 & $\begin{array}{l}\text { First and foremost, celebrate the moment with our member! Then go with your "gut". } \\
\text { Follow through with instinct that as more often than not it means you are on the right } \\
\text { path. Next, do your homework! Discuss with your peers the best way to execute your } \\
\text { plan and if need be adjust it so that your overall idea comes to fruition. Make sure that } \\
\text { you document your reasoning and tie up your loose ends. Until we have signed the last } \\
\text { document, sent that last payoff, scanned that last sheet you are still serving your member. } \\
\text { Do them the courtesy of following through on their custom tailored plan by ensuring it's } \\
100 \% \text { done so they don't run into any problems down the line }\end{array}$ \\
\hline 20 & $\begin{array}{l}\text { I could answer this question many varying ways depending on the situation, however the } \\
\text { generalized response would closest relate to the following: The first thing would be to } \\
\text { start with trusting and hearing the member and asking questions in order to better } \\
\text { understand what the member is wanting to achieve with the request. Everything has pros } \\
\text { and cons, what are they and what would make the most sense for the member long term, } \\
\text { and does the member understand them? Are there any "red flags" or pieces of the } \\
\text { situation that do make sense? If so, talk with the member, don't make assumptions. Gain } \\
\text { the knowledge to be able to make a decision with them. Be straight forward - Open and } \\
\text { honest goes a long way. And finally, take ownership of the long term success. Follow up } \\
\text { with the member down the road (put something structured in place so that this happens). } \\
\text { "Outside the box" thinking usually means following up with the member. Afterall, how do } \\
\text { you know if you are successful with your "Outside the Box" thought process if you are not } \\
\text { involved long term? }\end{array}$ \\
\hline
\end{tabular}




\section{Appendix B: Random Sample of 20 Employee Comments on Important Employee Attributes}

\begin{tabular}{|c|c|}
\hline $\begin{array}{l}\text { Employee } \\
\text { Comment }\end{array}$ & $\begin{array}{l}\text { You have been asked to speak with new employees at orientation. What personal } \\
\text { attributes would you say are important for an employee to be successful at [the } \\
\text { organization] in the months and years ahead? }\end{array}$ \\
\hline 1 & $\begin{array}{l}\text { Strong desire to help people. Independent thinker and worker. Someone who is not afraid to } \\
\text { think outside the box. Always, always, always starting with what the member wants. Make } \\
\text { certain you understand what they are requesting and use active listening. Sometimes a } \\
\text { member needs our help in this way to determine what they really want. Then don't ever feel } \\
\text { like anything is “off the table". We are empowered people who need to consistently need to } \\
\text { challenge conventional wisdom in what needs to be done. Each member is unique and need } \\
\text { to be treated as such and this sometimes requires help in ways that may not be considered } \\
\text { conventional. Search out as many different resources as you can here at [the organization] } \\
\text { and look to grow professionally utilizing these resources as we truly control our } \\
\text { development here }\end{array}$ \\
\hline 2 & $\begin{array}{l}\text { You have to be able to work with an open mind and an open heart. Preconceived notions of } \\
\text { banking or customer service should be eliminated because we operate differently than any } \\
\text { other institution I know of. You will have to be ready to adopt change on the fly and be able } \\
\text { to work without being micromanaged. You will have to trust yourself and be confident in } \\
\text { the decisions you make, because you are empowered to do what is best for our members! }\end{array}$ \\
\hline 3 & $\begin{array}{l}\text { Personal attributes that I consider important for someone to be successful at [the } \\
\text { organization] include: being open minded and flexible, non-judgmental, kind, resourceful, } \\
\text { being a good listener and communicator. Having the ability to relate to others in some way } \\
\text { and having a strong commitment to the success of our members and the organization }\end{array}$ \\
\hline 4 & $\begin{array}{l}\text { I feel I had one of the best life experiences working at a different financial institution gave } \\
\text { me a huge insight into what is offered outside of [the organization]. I would ask new } \\
\text { employees to take a few minutes, examine where they currently bank, but also seek out } \\
\text { information about local institutions, so that they can see just how different we are, and how } \\
\text { extraordinary our services are for our members }\end{array}$ \\
\hline 5 & $\begin{array}{l}\text { You need to really have empathy and sympathy for the member. After spending } 12 \text { years at } \\
\text { a community bank, I was disgusted with how some bankers treated less fortunate people or } \\
\text { customers that were struggling. We never can have that attitude with our members. They } \\
\text { may have made some poor choices, but bad things happen to good people, and many people } \\
\text { have never learned how to properly handle finances. By having Empathy and Sympathy for } \\
\text { people you will want to do what's right for them. Fortunately, everything is structured at } \\
\text { [the organization] to help us be straight-forward with our members. We tell them what the } \\
\text { rate is and why and what our recommendation is }\end{array}$ \\
\hline 6 & $\begin{array}{l}\text { Openness to learning new information is key. Although our commitment to doing what is } \\
\text { right for the member does not change, how we follow through on the commitment does. In } \\
\text { the last year the changes in epay, online banking, regulations for home equity loans, and how } \\
\text { we do first mortgages are examples of how we need to be open to change and learning new } \\
\text { things to be able to best help our members. }\end{array}$ \\
\hline 7 & $\begin{array}{l}\text { You have to care about people - we can teach you all of the process and procedure pieces we } \\
\text { want, but if you don't have the desire to help people you won't have success at [the } \\
\text { organization]. [the organization] is an awesome organization to work for and you receive a } \\
\text { lot of freedom to make decisions for our members every day, however there is a lot of } \\
\text { accountability that comes with that freedom so you need to have a strong desire and passion } \\
\text { to push yourself to help others everyday and to put others before yourself }\end{array}$ \\
\hline 8 & $\begin{array}{l}\text { My \#1 message would be that you need to be excited to help people and excited to have a } \\
\text { direct impact on members. No matter what your role is if that is not core to you as a person } \\
\text { you will not be successful or enjoy working at [the organization]. Whether you are in a } \\
\text { branch, work in IT or focus is financial accounting you need to have a core belief in what we } \\
\text { do. If you do not you will always struggle here and never enjoy what we do resulting in poor } \\
\text { performance }\end{array}$ \\
\hline
\end{tabular}




\begin{tabular}{|c|c|}
\hline $\begin{array}{l}\text { Employee } \\
\text { Comment }\end{array}$ & $\begin{array}{l}\text { You have been asked to speak with new employees at orientation. What personal } \\
\text { attributes would you say are important for an employee to be successful at [the } \\
\text { organization] in the months and years ahead? }\end{array}$ \\
\hline 9 & $\begin{array}{l}\text { I'd say one of the number one attributes to be a successful long-term employee is to be a } \\
\text { good listener. Our job comes down to a conversation between two people-in that } \\
\text { conversation you learn so much about the member-what they are passionate about, what } \\
\text { they are looking to [the organization] for help on. If you're perceptive and listening, you can } \\
\text { find out what they're looking for and the best way to help the member. Another attribute that } \\
\text { bides well is having empathy and also the ability to be creative and know that not everything } \\
\text { is black and white at Affinity - we care about our member's financial future and need to be } \\
\text { willing to do whatever it takes to get them in a good position. }\end{array}$ \\
\hline 10 & $\begin{array}{l}\text { Open Minded to the difference that we are compared to the last company that you worked } \\
\text { for Open to learning- we wear so many hats here that you will want to make sure that you } \\
\text { spend time learning all the roles you that you will be a part of teller, loan office, mortgage } \\
\text { officer, ect...Good listener - members, other member advisors, and your leader will need } \\
\text { you to listen to what they are trying to say to you. }\end{array}$ \\
\hline 11 & $\begin{array}{l}\text { Love what you do!, Trust that the organization has given you the empowerment to make the, } \\
\text { right decisions for our members, Take pleasure in learning something new about our } \\
\text { members so we can best meet their needs, Must have great interpersonal and customer } \\
\text { service skills, [the organization] is different from the other places you may have worked! }\end{array}$ \\
\hline 12 & $\begin{array}{l}\text { Flexibility, confidence in your own past experiences, willingness to learn on the fly with no } \\
\text { formal training classes. }\end{array}$ \\
\hline 13 & $\begin{array}{l}\text { To be successful at [the organization] you need to really care about others and be inspired to } \\
\text { connect with them and get to know them as people. Be passionate about the opportunity and } \\
\text { obligation to help make a difference in their lives. You need to enjoy getting outside of } \\
\text { yourself to help, fully understanding and believing that everyone will be successful by } \\
\text { putting our members first, then the organization and lastly ourselves. When our members } \\
\text { are successful that makes for a successful organization and when an organization is } \\
\text { successful you have successful employees }\end{array}$ \\
\hline 14 & $\begin{array}{l}\text { Having fun, working hard, and doing what is right for each member and their given } \\
\text { situation. Learn about our members, understand their goals, and your decisions and actions } \\
\text { will always be correct }\end{array}$ \\
\hline 15 & $\begin{array}{l}\text { Selflessness, openness to change, caring, integrity, being flexible and adaptable to member } \\
\text { and organizational needs, self motivation, good work ethic. }\end{array}$ \\
\hline 16 & $\begin{array}{l}\text { A strong passion to help others is critical. Employees must be willing to take on risks, and } \\
\text { not be afraid of doing new things. Change is good, even though it is scary at times. I think } \\
\text { most importantly, employees need to be themselves and bring their own unique personality } \\
\text { to [the organization]. It is important to be confident when making decisions, and trust that } \\
\text { the decisions made will be supported }\end{array}$ \\
\hline 17 & $\begin{array}{l}\text { The empowerment that you have also comes with responsibility. You need to be able to } \\
\text { make decisions on your own and need to be independent and self-reliant }\end{array}$ \\
\hline 18 & $\begin{array}{l}\text { I personally think that in order to be successful at [the organization] you need to be a } \\
\text { passionate person. It is also good to be organized. }\end{array}$ \\
\hline 19 & $\begin{array}{l}\text { I think the most important attribute to have is to have self-motivation and the ability to look } \\
\text { at situations from all different angles. Being able to motivate yourself to learn new things } \\
\text { and to think outside the box will allow you to go far as a member advisor }\end{array}$ \\
\hline 20 & $\begin{array}{l}\text { There are several personal attributes that I would tell an employee they would need to be } \\
\text { successful at [the organization]. Here are the ones that I see as most important: Fight to } \\
\text { serve, Connect with people, Take ownership and maintain accountability without a lot of } \\
\text { oversight, Trust our members and the organization, Be willing to challenge yourself, your } \\
\text { peers, and the organization, asking why for the member, Have confidence, despite not ever } \\
\text { being able to know everything, Know what you can contribute and bring it, Jump in and be } \\
\text { willing to learn as you go, Be willing to break from the comforts and constraints of the status } \\
\text { quo, being creative and maintaining high quality performance for our member }\end{array}$ \\
\hline
\end{tabular}

